\title{
Isotopic Power Materials Development Quarterly Progress Report for Period Ending June 30, 1976
}

A. C. Schaffhauser

\section{OAK RIDGE NATIONAL LABORATORY}




\section{DISCLAIMER}

This report was prepared as an account of work sponsored by an agency of the United States Government. Neither the United States Government nor any agency Thereof, nor any of their employees, makes any warranty, express or implied, or assumes any legal liability or responsibility for the accuracy, completeness, or usefulness of any information, apparatus, product, or process disclosed, or represents that its use would not infringe privately owned rights. Reference herein to any specific commercial product, process, or service by trade name, trademark, manufacturer, or otherwise does not necessarily constitute or imply its endorsement, recommendation, or favoring by the United States Government or any agency thereof. The views and opinions of authors expressed herein do not necessarily state or reflect those of the United States Government or any agency thereof. 


\section{DISCLAIMER}

Portions of this document may be illegible in electronic image products. Images are produced from the best available original document. 
Printed in the United States of America. Available from National Technical Information Service

U.S. Department of Commerce

5285 Port Royal Road, Springfield, Virginia 22161

Price: Printed Copy $\$ 4.50$; Microfiche $\$ 2.25$

This report was prepared as an account of work sponsored by the United States Government. Neither the United States nor the Energy Research and Development Administration/United States Nuclear Regulatory Commission, nor any of their employees, nor any of their contractors, subcontractors, or their employees, makes any warranty, express or implied, or assumes any legal liability or responsibility for the accuracy, completeness or usefulness of any information, apparatus, product or process disclosed, or represents that its use would not infringe privately owned rights. 


\author{
Contract No. W-7405-eng-26 \\ METALS AND CERAMICS DIVISION
}

ISOTOPIC POWER MATERIALS DEVELOPMENT QUARTERLY PROGRESS

REPORT FOR PERIOD ENDING JUNE 30, 1976

A. C. Schaffhauser

Date Published: September 1976

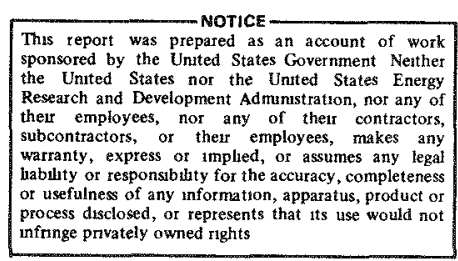

OAK RIDGE NATIONAL LABORATORY

Oak Ridge, Tennessee 37830

operated by

UNION CARBIDE CORPORATION

for the

ENERGY RESEARCI AND DEVELOPMENT ADMINISTRATION 
FOREWORD

This report is the third in a series of quarterly reports for Technology and Space Applications materials programs conducted by the Metals and Ceramics Division of Oak Ridge National Laboratory for the Nuclear Research and Applications Division of ERDA. These quarterly reports replace the monthly and annual reports previously issued on this work. The quaxterly reports will provide a more detailed technical discussion of work in progress than was possible in the monthly reports. Significant technical highlights are reported to ERDA and their contractors on a monthly basis in the Technical Highlights of Isotopic Power Materials Development at Oak Ridge National Laboratory results, issued as CF memo reports, with limited distribution.

This quarterly report contains four chapters: (1) "High-Temperature Alloys for Space Isotopic Heat Sources," Activity No. KJ 300102 3, 189a No. 00001; (2) "Physical and Mechanical Metallurgy of Heat-Source Containment Materials," Activity No. KJ 300102 3, 189a No. 00002;

(3) "Isotope Brayton System Materials Support," Activity No. KJ 300102 2, $189 a$ No. 00006; and (4) "Space Nuclear Flight Systems Hardware," Activity No. KJ 300103 2, 189a No. 00003.

Recent previous reports covering work on these programs are listed below:

Isotopic Power Materials Development Quarterly Report

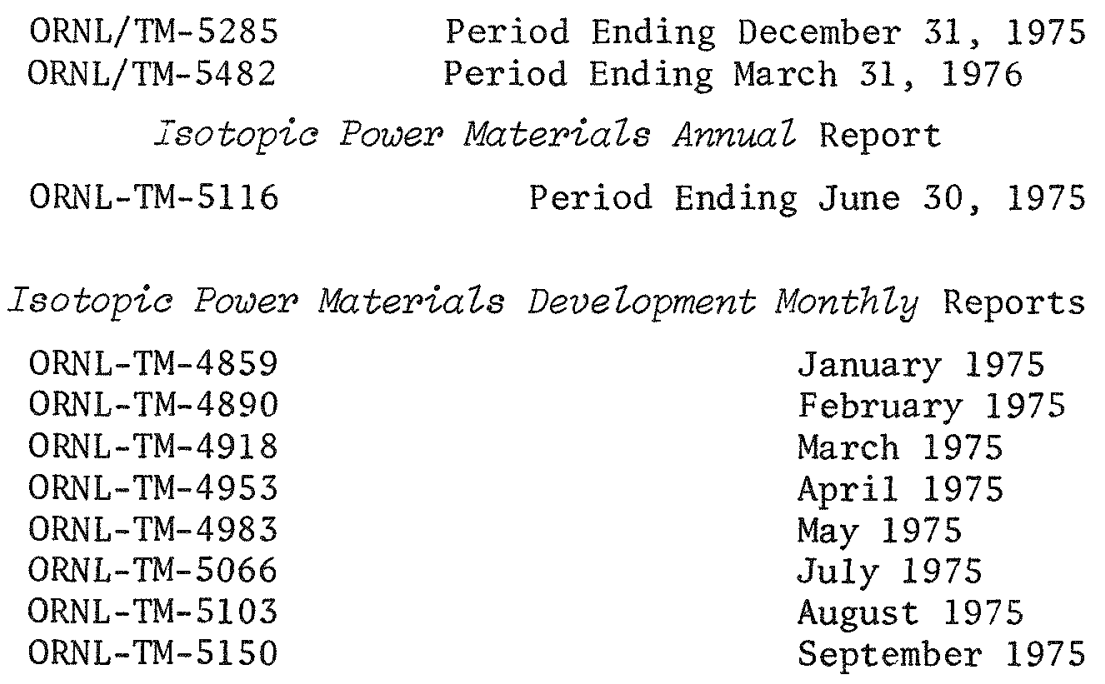


Copies of these reports are available from the U.S. Energy Research and Development Administration, Technical Information Center, P.0. Box 62, Oak Ridge, Tennessee 37830. 
CONTENTS

SUMMARY . . . . . . . . . . . . . . . . . . . . . . . . vii

1. HIGH-TEMPERATURE ALLOYS FOR SPACE ISOTOPIC HEAT SOURCES . . . . . . 1

1.1 Introduction . . . . . . . . . . . . . . . . . . 1

1.2 Iridium Alloys . . . . . . . . . . . . . . . . . . . . 1

1.2.1 Development of Improved $\mathrm{I} r-0.3 \% \mathrm{~W}$ Alloys . . . . . . . 1

1.2.2 Development of Advanced Iridium Alloys

with Dopants . . . . . . . . . . . . . 5

1.3 Pt-Rh-W Alloys . . . . . . . . . . . . . . . 7

1.3.1 Pt-3008 Scale-Up and Fabrication Development . . . . 7

1.3.2 Characterization of Pt-3008 Scale-Up Heat . . . . . . . 10

1.3.3 Welding of Pt-3008 Alloy . . . . . . . . . 11

1.4 Ruthenium and Rhodium Alloys . . . . . . . . . . . . 13

1.4.1 Ruthenium-P1atinum Alloys . . . . . . . . . . 13

1.4 .2 Rhodium Alloys . . . . . . . . . . . . . . 13

1.5 References . . . . . . . . . . . . . . . . 15

2. PHYSICAL AND MECHANICAL METALLURGY OF HEAT-SOURCE

CONTAINMENT MATERIALS . . . . . . . . . . . . . . . . . . . 17

2.1 Introduction . . . . . . . . . . . . . . . . 17

2.2 Characterization of Impact Properties . . . . . . . . . . 17

2.2.1 Impact Properties of Iridium Alloys . . . . . . . . 17

2.2.1.1 DOP-4 Dopant Effect . . . . . . . . 17

2.2.1.2 Thorium Concentration Effect... . . . . . 19

2.2.1.3 Impact Temperature Effect . . . . . . . . 19

2.2.2 Effect of Long-Term Heat Treatment on Impact
Properties of Ir-0.3\% W Alloys . . . . . . . 22

2.3 Microanalysis Studies . . . . . . . . . . . . 26

2.3.1 Thorium Segregation to Grain Boundaries

in $\operatorname{Ir}-0.3 \% \mathrm{~W}$. . . . . . . . . . . . . . . . . 26

2.3.2 Auger Electron Spectroscopy Analysis of DOP-17 and DOP-18............ 28

2.3.3 Phosphorus Segregation to Grain Boundaries in $\mathrm{I} r-0.3 \% \mathrm{~W}$. . . . . . . . . . 28 
2.4 Environmental and Impurity Effects . . . . . . . . . . 28

2.4.1 Pt-3008 Air Oxidation . . . . . . . . . . . . 28

2.4.2 Grain Size Effects in Pt-3008.......... . 29

2.5 References .................... 30

3. ISOTOPE BRAYTON SYSTEM MATERIALS SUPPORT . . . . . . . . . . . . 33

3.1 Introduction . . . . . . . . . . . . . . . . . . . . 33

3.2 C-103 Gaseous Interactions . . . . . . . . . . . . . 33

3.2.1 Creep Properties of $\mathrm{C}-103$ in Contaminating Environments . . . . . . . . . . . . . . . . 33

3.2.2 Effect of Gaseous Environment on Embrittlement of $\mathrm{C}-103$................ . 34

3.3 Alternate Alloys . . . . . . . . . . . . . . . 37

3.3.1 Creep Properties of Molybdenum-Rhenium Alloys . . . . 37

3.3.2 Creep Properties of Pt-3008 . . . . . . . . . . 37

3.4 Welding and Brazing Evaluation . . . . . . . . . . . . 38

3.5 References . . . . . . . . . . . . . . . . . 38

4. SPACE NUCLEAR FLIGHT SYSTEMS HARDWARE . . . . . . . . . . . . 39

4.1 Introduction . . . . . . . . . . . . . . . . . . . . 39

4.2 Production of Ir-0.3\% W Forming Disks and Foil . . . . . . . 39

4.3 Impact Properties of Production Material . . . . . . . . . . 42

4.4 References ...................... . . 44 
SUMMARY

\section{HIGH-TEMPERATURE ALLOYS FOR SPACE ISOTOPIC HEAT SOURCES}

Optimization of dopant additions to improve the high-temperature mechanical properties of $\operatorname{Ir}-0.3 \% \mathrm{~W}$ alloys was continued. Tensile tests at $1370^{\circ} \mathrm{C}$ show that the yeild and tensile strengths increase with increasing thorium content between $0-500 \mathrm{ppm}$ while maintaining greater than $50 \%$ elongation. Aluminum additions also appear beneficial to the high-temperature properties, and alloys containing both thorium and aluminum additions have been prepared. Additions of $\mathrm{Fe}, \mathrm{Ni}$, and $\mathrm{Rh}$ up to $80 \mathrm{ppm}$ have no effect on the properties.

Doped iridium alloys containing $2 \% \mathrm{Ru}$ are also being evaluated in an attempt to gain a further improvement in properties. Tensile tests at 650 and $760^{\circ} \mathrm{C}$ show a less ductile fracture mode at $650^{\circ} \mathrm{C}$ for alloys containing $2 \% \mathrm{Ru}$ as compared to alloys without ruthenium. However, the alloys containing $2 \% \mathrm{Ru}$ had a smaller grain size after annealing at $1500^{\circ} \mathrm{C}$.

Characterization of the first $\mathrm{Pt}-3008$ scale-up ingot was continued. Recrysta11ization studies ( 1 -hr heat treatments) showed no recrystallization up to $950^{\circ} \mathrm{C}$ and complete recrystallization with a large drop in hardness at $1050^{\circ} \mathrm{C}$. At $1000^{\circ} \mathrm{C}$, the microstructure was partially recrystallized with some differences in the amount of recrystallization and hardness depending on sample location (nose, center, or tail of extrusion) and amount of cold finish rolling $(40-50 \%)$. Tensile tests at 760 and $1093^{\circ} \mathrm{C}$ on sheet specimens rolled from different sections of the extrusion showed slightly higher yield strengths and lower ductilities on specimens from the center of the extrusion as compared to specimens from the nose and tail sections. Evaluation of the room-temperature mechanical properties of electron-beam welds in the scale-up heat shows that the yield strength of the welds is equivalent to annealed base metal; however, the maximum weld ductility is $4 \%$ at room temperature for a post-weld heat treatment of $1 \mathrm{hr}$ at $1200^{\circ} \mathrm{C}$.

Ruthenium-platinum and rhodium-ruthenium alloys are being evaluated as potential lower-density and/or lower-cost isotope fuel cladding materials for space applications. Experiments show that greater than 20 at. $\% \mathrm{Pt}$ is 
required to obtain a face-centered cubic ( $f c c$ ) structure necessary for good fabricability. A Rh-20\% Ru alloy had good fabricability as compared to pure rhodium, and ductility was increased by annealing at $900^{\circ} \mathrm{C}$.

2. PHYSICAL AND MECHANICAL METALLURGY OF HEAT-SOURCE CONTAINMENT MATERIALS

Tensile impact tests at $1350^{\circ} \mathrm{C}$ and $85 \mathrm{~m} / \mathrm{sec}(280 \mathrm{fps})$ were performed on a number of developmental Ir $-0.3 \% \mathrm{~W}$ alloys after severe temperature exposures at 1500 and $1800^{\circ} \mathrm{C}$ to isolate and optimize the dopant concentrations for maximum ductility. The impact ductility increases linearly from $<10 \%$ to $>25 \%$ with thorium additions up to $200 \mathrm{ppm}$ and plateaus between 200 and $1000 \mathrm{ppm}$. At the $30 \mathrm{ppm}$ Th level, aluminum additions of $40 \mathrm{ppm}$ are also effective in increasing impact ductility to $>15 \%$. At impact temperatures below $1200^{\circ} \mathrm{C}$, the ductility of all alloys is severely reduced; however, the $200 \mathrm{ppm}$ Th alloy was the most ductile alloy $\left(15 \%\right.$ elongation) at $950^{\circ} \mathrm{C}$. Impact tests of specimens aged $2000 \mathrm{hr}$ at $1330^{\circ} \mathrm{C}$ continue to show the improved ductility ( 24 vs $8 \%$ ) of the DOP-4 alloy as compared to undoped $\operatorname{Ir}-0.3 \% \mathrm{~W}$.

Auger analysis of Ir-0.3\% $\mathrm{W}$ alloys shows that the grain boundary concentration of thorium is constant at 3-5 at. \% for alloys containing 5-1000 ppm Th. Alloying with $2 \%$ Ru does not change this grain boundary concentration of thorium.

Tensile specimens of $\mathrm{Pt}-3008$ oxidized $6000 \mathrm{hr}$ continue to show the same effects as observed after $3000 \mathrm{hr}$. No effect on properties is observed at a $600^{\circ} \mathrm{C}$ exposure. At 800 and $1000^{\circ} \mathrm{C}$ exposures, the ductility at the exposure temperature is reduced to less than $2.5 \%$ due to formation of tungsten oxide phases in the grain boundaries.

\section{ISOTOPE BRAYTON SYSTEM MATERIALS SUPPORT}

The mechanical properties of $\mathrm{C}-103$ exposed to a simulated Brayton system atmosphere containing $1.3 \times 10^{-3} \mathrm{~Pa}\left(1 \times 10^{-5}\right.$ torr $) \mathrm{Co}$ at $1000^{\circ} \mathrm{C}$ were determined. The creep rate at $1000^{\circ} \mathrm{C}$ and $48.2 \mathrm{MPa}(7 \mathrm{ksi})$ stress was reduced in the carbon monoxide atmosphere as compared to the creep observed in ultrahigh vacuum. The specimen gained about $2000 \mathrm{ppm} 0$ and 
$1400 \mathrm{ppm} \mathrm{C}$ during the 300-hr test. The room-temperature tensile ductility after the creep test was reduced to $4.3 \%$. Tensile tests at 25,850 , and $1000^{\circ} \mathrm{C}$ of specimens exposed to the same atmosphere for $200 \mathrm{hr}$ showed a reduction of ductility to about $2.5 \%$ as compared to $20-30 \%$ for control specimens. Creep tests of alternate alloys for the Brayton system show that at $1000^{\circ} \mathrm{C}$, molybdenum-rhenium alloys are equivalent or stronger than C-103 whereas the Pt-3008 alloy is much weaker.

Tensile specimens of Hastelloy $X$ brazed to itself with Palniro 7 braze alloy and Hastelloy $X$ brazed to $C-103$ with Coast Metals 50 braze alloy have been prepared for testing and aging.

\section{SPACE NUCLEAR FLIGHT SYSTEMS HARDWARE}

A total of 126 forming disks of doped $\mathrm{Ir}-0.3 \% \mathrm{~W}$ alloy and $1000 \mathrm{~cm}^{2}$ of foil were fabricated and certified for MHW heat sources. The deliveries completed the requirements for the MJS mission and meet the requested schedule for the initial disks for the HPG/Mod-3 mission. The surface microdelaminations observed in some samples from the previous forming disks were determined to be an artifact of metallographic specimen preparation and they were eliminated by using a different specimen mounting material. Additional tensile impact tests of HD-series production forming disks show impact ductilities of 19 to $20 \%$. 


\section{HIGH-TEMPERATURE ALLOYS FOR SPACE ISOTOPIC HEAT SOURCES*}

\subsection{Introduction}

The objective of this program is to develop and qualify improved alloys for encapsulation of ${ }^{238} \mathrm{PuO}_{2}$ isotope fuels used for heat sources for high-temperature energy conversion systems for space and terrestrial power applications. We are developing a series of high-melting-point, noble-base alloys having the required mechanical properties, oxidation resistance, and stability in a heat-source environment under both operational and potential severe accident conditions. Our activities are divided between improved iridium alloys, Pt-Rh-W alloys, and lighter-weight ruthenium and rhodium alloys. Tasks on these materials include alloy and fabrication development, characterization, and supply of materials and hardware for qualification testing.

\subsection{Iridium Alloys}

1.2.1 Development of Improved $\operatorname{Ir}-0.3 \% \mathrm{~W}$ Alloys $-\mathrm{C} . \mathrm{T}$. Liu and $\mathrm{H}$. Inouye We have doped $\operatorname{Ir}-0.3 \% \mathrm{~W}$ alloys with different levels of thorium to improve the metallurgical and mechanical properties. The tensile properties of DOP-21 and -22 were determined at $1370^{\circ} \mathrm{C}$ [at a crosshead speed of $5.1 \mathrm{~mm} / \mathrm{min}(0.2 \mathrm{in.} / \mathrm{min})]$ after a standard heat treatment of $1 \mathrm{hr}$ at $1500^{\circ} \mathrm{C}$. The tensile data are presented in Table 1.1 and are compared with WTh-1 and undoped WG. The thorium content in these alloys is also listed in Table 1.1. The yield and tensile strengths increase with thorium content. All the alloys had more than $50 \%$ elongation and showed ductile rupture at $1370^{\circ} \mathrm{C}$.

The microstructures of the DOP-21 alloy after short-term heat treatments at 1500 and $1800^{\circ} \mathrm{C}$ are shown in Fig. 1.1(a), (b), and (c). The heattreated specimens show a recrystallized structure with second-phase particles (probably ThIr5) within grains and on grain boundaries. The grain

\footnotetext{
${ }^{*}$ Progress on work performed under Activity No. KJ 300102 3, 189a
} No. 00001 . 
Table 1.1. Tensile Properties ${ }^{\mathrm{a}}$ of Doped and Undoped $\operatorname{Ir}-0.3 \% \mathrm{~W}$ Sheet Specimens ${ }^{b}$ Tested at $1370^{\circ} \mathrm{C}$

\begin{tabular}{|c|c|c|c|c|c|}
\hline \multirow{2}{*}{$\begin{array}{l}\text { Alloy } \\
\text { Specimen }\end{array}$} & \multirow{2}{*}{$\begin{array}{c}\text { Nominal Dopant } \\
\text { Concentration } \\
\text { (ppm) }\end{array}$} & \multicolumn{2}{|c|}{ Strength, MPa (ksi) } & \multirow{2}{*}{$\begin{array}{c}\text { Elongation } \\
\left(\frac{0}{0}\right)\end{array}$} & \multirow{2}{*}{$\begin{array}{l}\text { Fracture } \\
\text { Mode }^{c}\end{array}$} \\
\hline & & Yield & Tensile & & \\
\hline WG & None & $38.6(5.6)$ & $177.8(25.8)$ & 55.2 & DR \\
\hline WTh-1 & $50 \mathrm{Th}$ & $48.2(7.0)$ & $191.5(27.8)$ & 66.1 & $\mathrm{DR}$ \\
\hline DOP -22 & $100 \mathrm{Th}$ & $58.6(8.5)$ & $193.6(28.1)$ & 53.8 & DR \\
\hline DOP-21 & $500 \mathrm{Th}$ & $73.0(10.6)$ & $221.2(32.1)$ & 56.0 & $\mathrm{DR}$ \\
\hline DOP-15 & $30 \mathrm{Th}, 80 \mathrm{Fe}$ & $50.3(7.3)$ & $188.1(27.3)$ & 58.9 & DR \\
\hline DOP-13 & $30 \mathrm{Th}, 40 \mathrm{Al}$ & $54.4(7.9)$ & $188.1(27.3)$ & 53.2 & $\mathrm{DR}$ \\
\hline DOP-16 & $30 \mathrm{Th}, 80 \mathrm{Fe}, 40 \mathrm{~A} 1$ & $54.4(7.9)$ & $186.7(27.1)$ & 55.3 & DR \\
\hline$D O P-4(\operatorname{Ir}-0.3 \% W)-10$ & $\begin{array}{c}30 \mathrm{Th}, 80 \mathrm{Fe}, 40 \mathrm{Al} \\
16 \mathrm{Ni}, 75 \mathrm{Rh}\end{array}$ & $55.8(8.1)$ & $189.5(27.5)$ & 53.6 & $\mathrm{DR}$ \\
\hline
\end{tabular}

${ }^{a}$ Tested at a crosshead speed of $5.1 \mathrm{~mm} / \mathrm{min}(0.2 \mathrm{in.} / \mathrm{min})$ in vacuum.

$\mathrm{b}_{\mathrm{All}}$ specimens annealed $1 \mathrm{hr}$ at $1500^{\circ} \mathrm{C}$ before testing.

$c_{D R}=$ ductile rupture. 

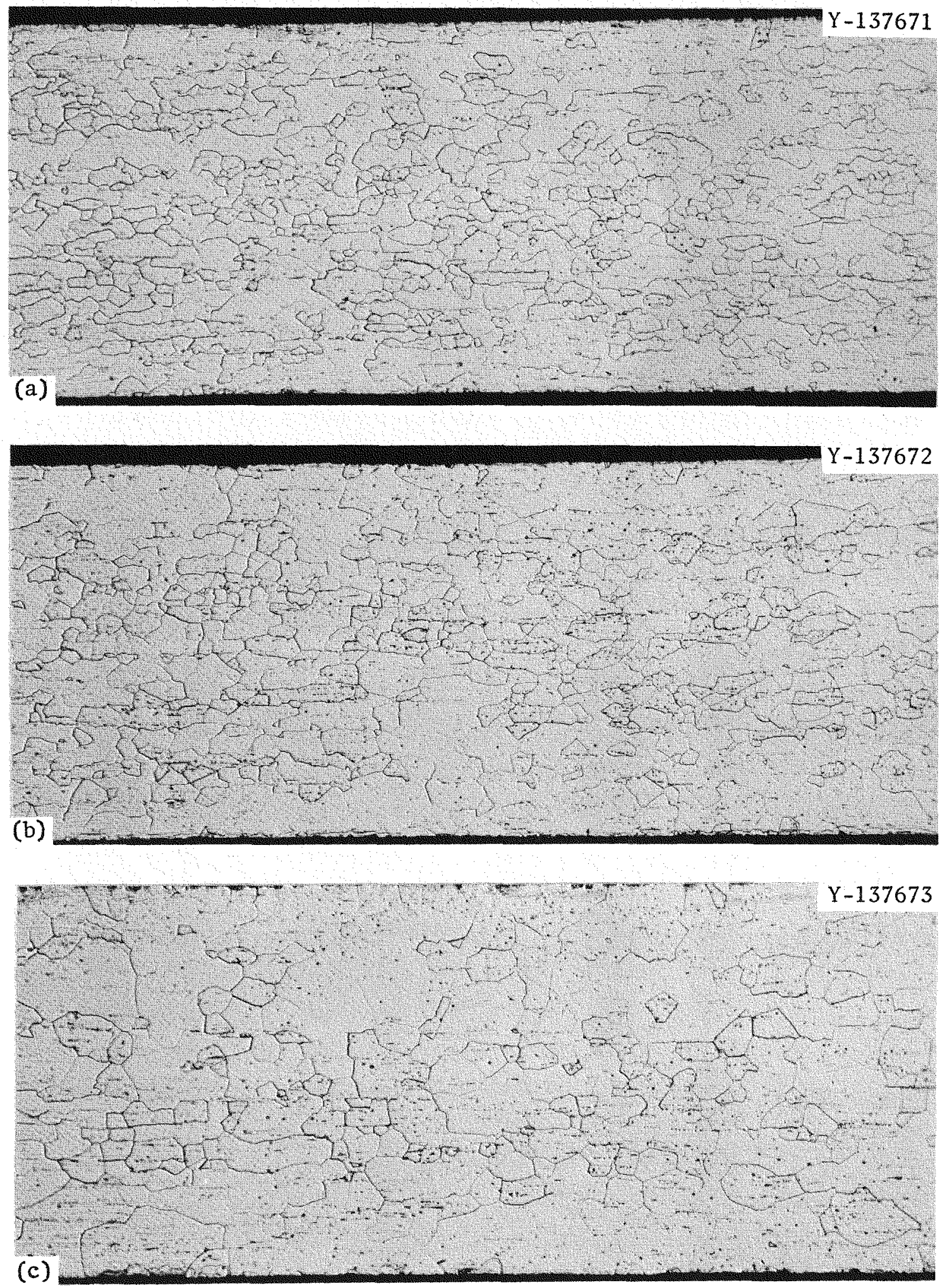

Fig. 1.1 Microstructures of DOP-21 (500 ppm Th) Specimens Heat Treated (a) $1 \mathrm{hr}$ at $1500^{\circ} \mathrm{C}$, (b) $19 \mathrm{hr}$ at $1500^{\circ} \mathrm{C}$, and (c) $1 \mathrm{hr}$ at $1500^{\circ} \mathrm{C}$ Plus $1 \mathrm{hr}$ at $1800^{\circ} \mathrm{C}$ Plus $1 \mathrm{hr}$ at $1500^{\circ} \mathrm{C}$. $100 \times$. 
size of DOP-21 is comparable to WTh-2 (doped with $1000 \mathrm{ppm}$ Th), but is finer than that of DOP-14 (doped with $200 \mathrm{ppm}$ Th) under the same heat treatments. A comparison of the grain sizes of the thorium-doped alloys is shown on p. 20 of this report. The tensile impact properties of DOP-21 are reported in the "Physical and Mechanical Metallurgy of Heat-Source Containment Materials" chapter (chapter 2 of this report).

The published partial phase diagram of iridium-thorium system indicates ${ }^{1}$ that thorium may lower the melting point of iridium. The eutectic temperature between iridium-rich solid solution and $\operatorname{ThIr}_{5}$ (the first compound formed on the iridium-rich end) was estimated to be greater than $1500^{\circ} \mathrm{C}$. To determine the melting point of the thorium-doped alloys, the specimens will be quickly heated to preset temperature and kept at that temperature for 10 min. The preliminary result indicates that DoP-14 (200 ppm Th) shows no indication of melting at $2000^{\circ} \mathrm{C}$.

The tensile properties of the Ir-0.3\% $\mathrm{W}$ alloys doped with DOP -4 dopants were determined at $1370^{\circ} \mathrm{C}$. The results in Table 1.1 show that DOP-4 dopants do not affect the strength and ductility of DOP-4, $-13,-15$, and -16 at $1370^{\circ} \mathrm{C}$. Al1 the alloys fractured by ductile rupture with close to $100 \%$ reduction of area. The tensile impact properties of these alloys are reported in chapter 2 of this report.

The previous studies ${ }^{2}$ indicate that doping with aluminum at a level of $40 \mathrm{ppm}$ has a significant effect on grain structure and impact properties of Ir-0.3\% W. To further characterize and optimize the aluminum effects, four new alloys, doped with aluminum and a combination of aluminum and thorium, were prepared by arc melting. The four alloys are (1) DOP-23 - Ir $-0.3 \% \mathrm{~W}$ alloy doped with 40 ppm Al alone; (2) DOP-24 - Ir-0.3\% W alloy doped with $30 \mathrm{ppm}$ Th and $100 \mathrm{ppm} \mathrm{AI;} \mathrm{(3)} \mathrm{DOP-25} \mathrm{-} \mathrm{Ir-0.3 \%} \mathrm{W} \mathrm{alloy} \mathrm{doped} \mathrm{with} 30 \mathrm{ppm}$ Th and $200 \mathrm{ppm} \mathrm{Al}$; and (4) DOP-4( $\operatorname{Ir}-0.3 \% \mathrm{~W})-11$ - skulls and heads of production material HD-460 and -461 with $40 \mathrm{ppm} \mathrm{Al}$ added (This ingot was prepared for studying the upgrading of recycled production materia1.). The four ingots were then fabricated into $0.76-\mathrm{mm}-(0.030-$ in.- $)$ thick sheets using the WGD production rolling schedule. ${ }^{3}$ The evaluation of their properties is in progress. 
1.2.2 Development of Advanced Iridium Alloys with Dopants - C. T. Liu

Tensile properties of the two advanced alloys, DOP-17 ( Ir-2\% Ru-0.3\% W) doped with $200 \mathrm{ppm} T \mathrm{Th}$ ) and DOP-18 ( $\mathrm{Ir}-2 \% \mathrm{Ru}-0.5 \% \mathrm{~W}$ doped with DOP-4 dopants), were determined at 650 and $760^{\circ} \mathrm{C}$ after a standard heat treatment of $1 \mathrm{hr}$ at $1500^{\circ} \mathrm{C}$. The results are presented in Table 1.2 . The strength of DOP-17 is

Table 1.2. Tensile Properties ${ }^{\mathrm{a}}$ of DOP-17 (Ir-2\% Ru-0.3\% W Doped with $200 \mathrm{ppm} \mathrm{Th}$ ), DOP-18 (Ir-2\% Ru-0.5\% W Doped with DOP-4 Dopants)

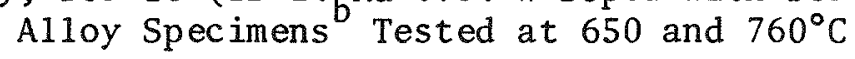

\begin{tabular}{|c|c|c|c|c|}
\hline \multirow{2}{*}{$\begin{array}{l}\text { Alloy } \\
\text { Number }\end{array}$} & \multicolumn{2}{|c|}{ Strength, $\mathrm{MPa}(\mathrm{ksi})$} & \multirow{2}{*}{$\begin{array}{c}\text { Elongation } \\
(\%)\end{array}$} & \multirow{2}{*}{ Fracture Mode ${ }^{c}$} \\
\hline & Yield & Tensile & & \\
\hline \multicolumn{5}{|c|}{$\underline{650^{\circ} \mathrm{C}}$} \\
\hline DOP -17 & $126.1(18.3)$ & $670.4(97.3)$ & 35.1 & GBS (Ma) and TF (Mi) \\
\hline DOP-18 & $98.5(14.3)$ & $604.3(87.7)$ & 36.5 & GBS (Ma) and TF (Mi) \\
\hline \multicolumn{5}{|c|}{$760^{\circ} \mathrm{C}$} \\
\hline DOP-17 & $125.4(18.2)$ & $559.5(81.2)$ & 41.1 & Mainly $\mathrm{TF}$ \\
\hline DOP-18 & $86.1(12.5)$ & $485.8(70.5)$ & 40.2 & Mainly $\mathrm{TF}$ \\
\hline
\end{tabular}

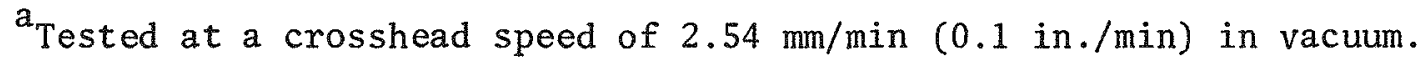

$\mathrm{b}_{\mathrm{All}}$ specimens annealed $1 \mathrm{hr}$ at $1500^{\circ} \mathrm{C}$ before testing.

$\mathrm{C}_{\mathrm{GBS}}=$ grain-boundary separation; $\mathrm{TF}=$ transgranular fracture; $\mathrm{Ma}=$ major fraction; and $\mathrm{Mi}=$ minor fraction.

higher than that of DOP-18, but the ductility of both alloys is about the same. The DOP-17 and -18 alloys showed mixed fracture modes of grainboundary separation (major fraction) and transgranular fracture (minor fraction) at $650^{\circ} \mathrm{C}$ while the $\operatorname{Ir}-0.3 \% \mathrm{~W}$ alloys doped with the same dopants exhibited ${ }^{2}$ mainly transgranular fracture. These two alloys showed completely transgranular fracture at $760^{\circ} \mathrm{C}$.

Figure 1.2 compares the microstructures of DOP-17 and -18 . The specimens heat treated at $1500^{\circ} \mathrm{C}$ show a recrystallized structure with some second-phase particles within the grains and on grain boundaries. The DOP-17 alloy has finer grain structure than DOP-18 under the same heat treatment conditions. In terms of number of grains across the specimen thickness, DOP-17 had 27.8 and 21.6 as compared to 22.0 and 12.2 for DOP -18 

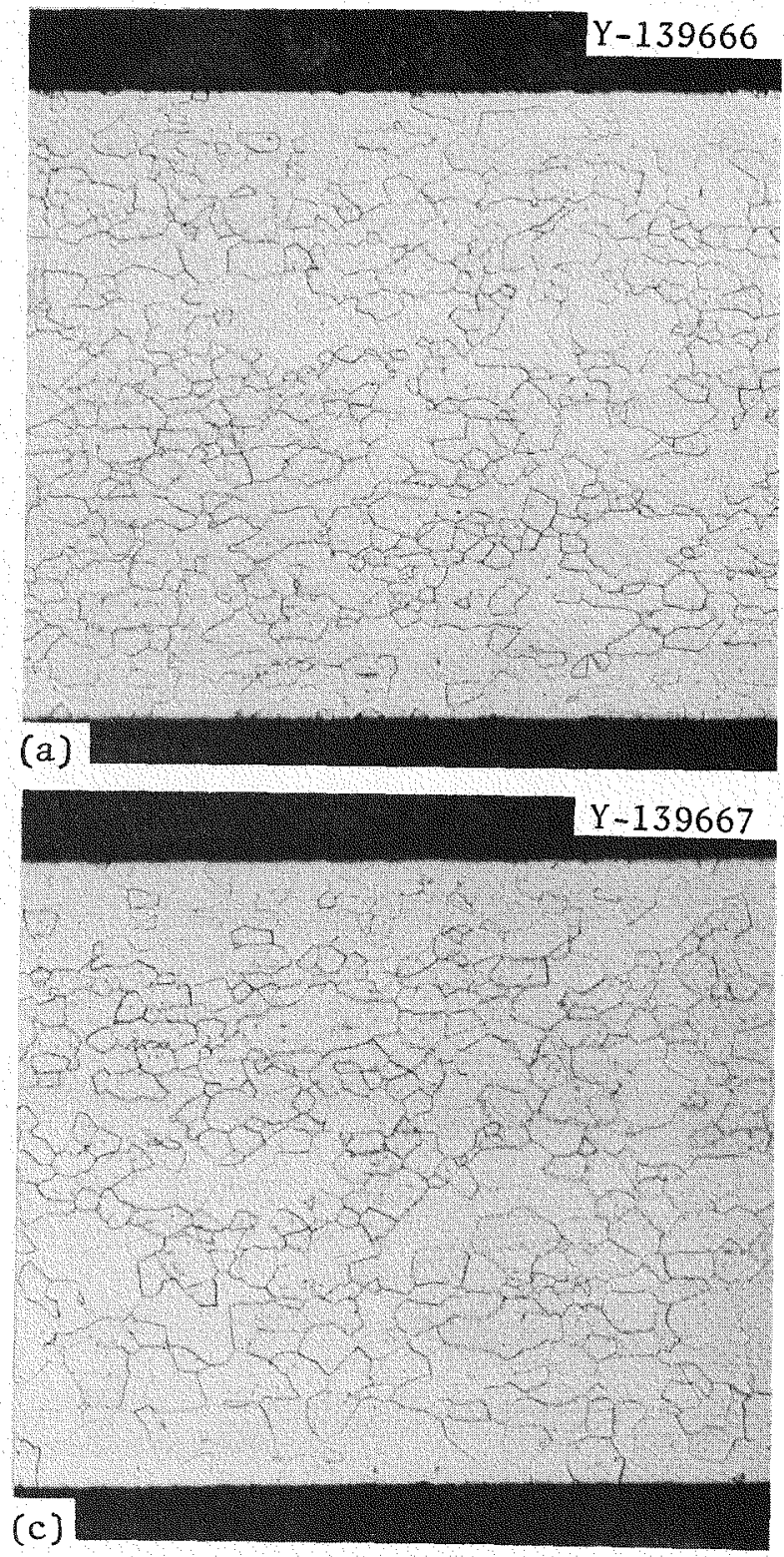
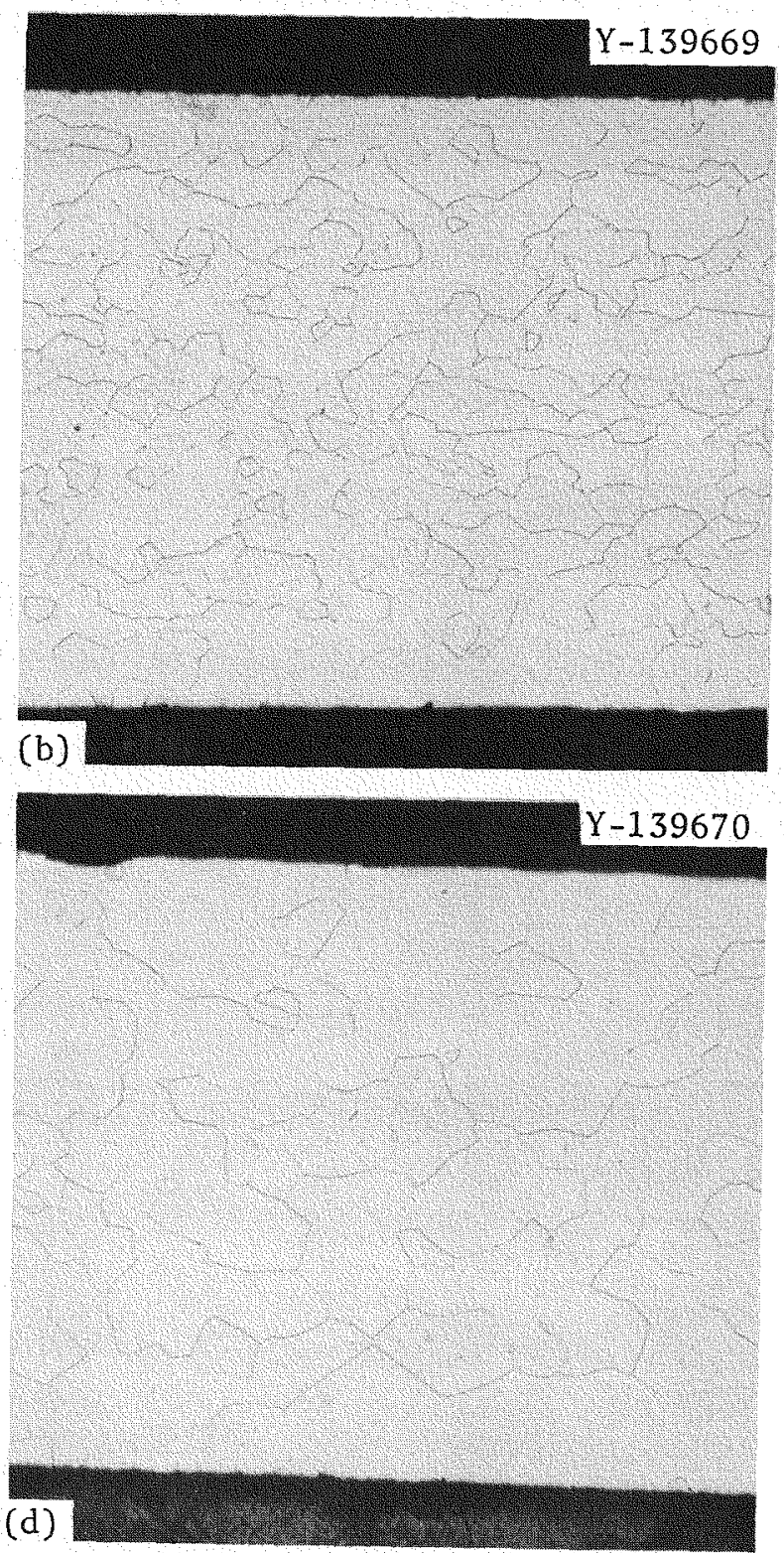

(d)

Fig. 1.2. Microstructures of DOP -17 (Ir-2\% Ru-0.3\% W Doped with 200 ppm Th) and DOP-18 (Ir-2\% Ru-0.5\% W Doped with DOP-4 Dopants) (a) DOP-17 annealed $1 \mathrm{hr}$ at $1500^{\circ} \mathrm{C}$; (b) DOP-18 annealed $1 \mathrm{hr}$ at $1500^{\circ} \mathrm{C}$; (c) DOP -17 annealed $19 \mathrm{hr}$ at $1500^{\circ} \mathrm{C}$; and (c) DOP-18 annealed $19 \mathrm{hr}$ at $1500^{\circ} \mathrm{C}$. 
after 1 - and $19-\mathrm{hr}$ annealing at $1500^{\circ} \mathrm{C}$. The grain size of DOP-17 and -18 is finer than that of the $\operatorname{Ir}-0.3 \% \mathrm{~W}$ alloys doped with the same dopants.

\subsection{Pt - Rh-W Alloys}

1.3.1 Pt-3008 Scale-Up and Fabrication Development - M. M. Martin

Retention of a fibrous structure in fabricated $\mathrm{Pt}-3008(\mathrm{Pt}-30 \% \mathrm{Rh}-8 \% \mathrm{~W})$ sheet after stress relieving improves formability of this alloy. Figure 1.3 shows the effect of various heat treatments of 1-hr duration at temperatures in vacuum on hardness of cold-rolled material. As reported previously, ${ }^{4}$ the

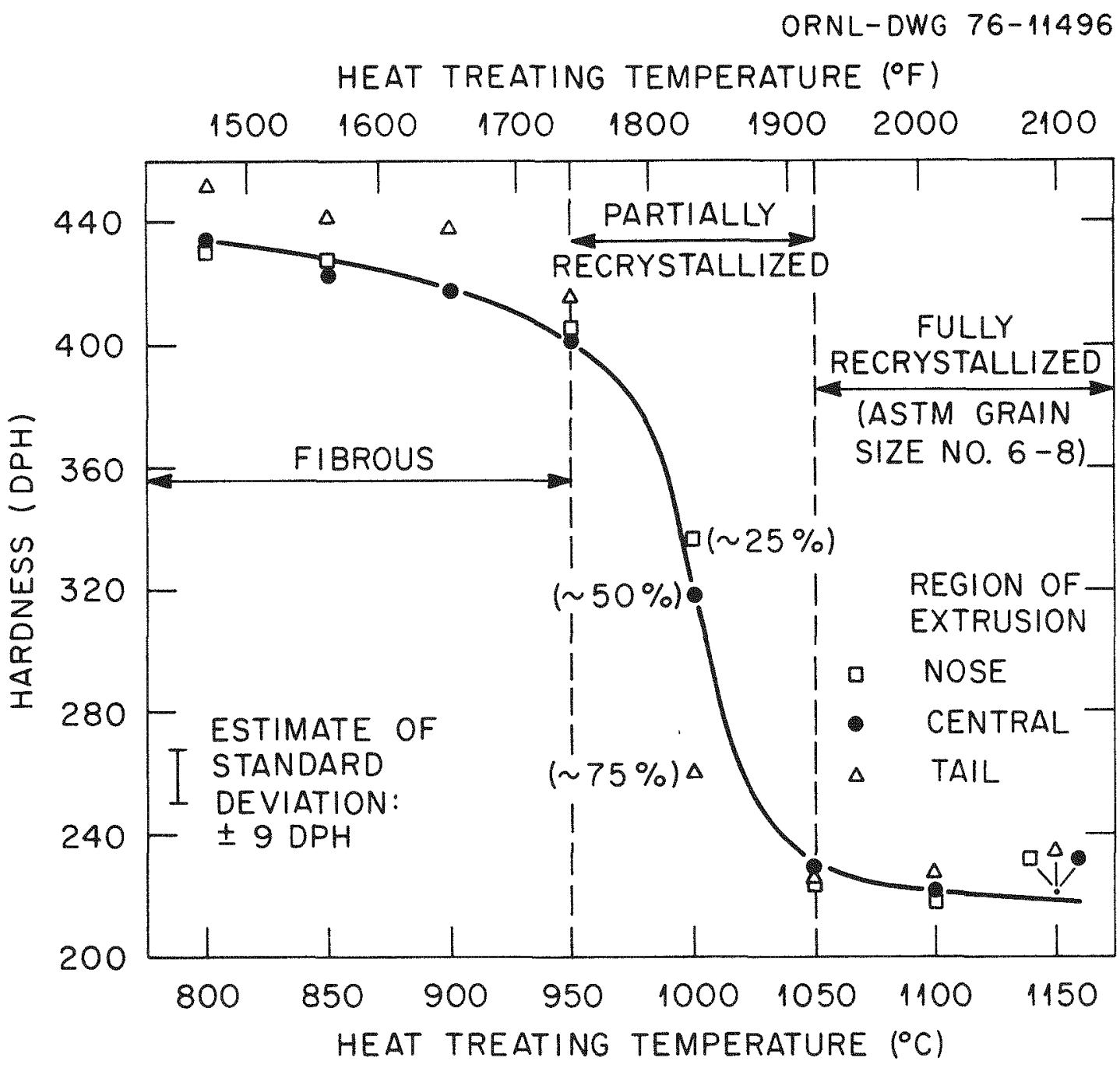

Fig. 1.3. Effect of Heat-Treating Temperature on Diamond-Pyramid Hardness Number of Pt-3008 Sheet Fabricated from El Extruded Bar. 
fabrication history for the specimens included extrusion from a consumable vacuum-arc-melted scale-up ingot followed by hot rolling and annealing at $1200^{\circ} \mathrm{C}\left(2192^{\circ} \mathrm{F}\right)$, and warm rolling and stress relieving at $1000^{\circ} \mathrm{C}\left(1832^{\circ} \mathrm{F}\right)$. Final sheet thickness was obtained by cold rolling. Specimens from the tail of the extrusion were final cold rolled $50 \%$ in thickness while those from the nose and middle were final cold rolled $40 \%$.

The hardnesses of the cold-worked Pt-3008 materials (as shown in Fig. 1.3) decrease sharply with increasing temperature between 950 and $1050^{\circ} \mathrm{C}$ $\left(1742\right.$ and $\left.1922^{\circ} \mathrm{F}\right)$. This reduction of hardness is more pronounced for sheets that were reduced $50 \%$ than $40 \%$ at room temperature. The specimens with the higher percentage of cold work also exhibited maximal initial hardness of about 400-450 DPH, as revealed at the lower heat-treating temperatures in Fig. 1.3. At and above $1050^{\circ} \mathrm{C}\left(1922^{\circ} \mathrm{F}\right)$, however, all showed similar values of about 219-228 \pm 9 DPH.

Figure 1.4 shows microstructures of three of the cold-worked specimens that were heat treated at 950,1000 , and $1050^{\circ} \mathrm{C}\left(1742,1832\right.$, and $\left.1922^{\circ} \mathrm{F}\right)$. These photomicrographs show all principal differences in structure from all heat treatments and form the basis to divide Fig. 1.3 into three distinct temperature regions. The resultant structure is either fibrous, partially recrystallized, or fully recrystallized. That is, all of the cold-worked specimens from nose, center, and tail of the extrusion retain their beforeheat-treatment fibrous structure up to and between $900-950^{\circ} \mathrm{C}\left(1652-1742^{\circ} \mathrm{F}\right)$; they then begin to recrystallize either at or slightly above the higher temperature. After $1 \mathrm{hr}$ at $1000^{\circ} \mathrm{C}\left(1832^{\circ} \mathrm{F}\right)$, the examination of specimens from the nose, center, and tail portions of the extrusion reveals structures in which about 25, 50, and $75 \%$, respectively, contain equiaxed grains. These degrees of recrystallization are given in Fig. 1.3 in parentheses beside the corresponding plotted average hardness numbers. In the region between 950 and $1050^{\circ} \mathrm{C}\left(1742\right.$ and $\left.1922^{\circ} \mathrm{F}\right)$ where partial recrysta11ization occurs, a lower hardness number apparent1y corresponds to an increase in area of equiaxed grains. At and above $1050^{\circ} \mathrm{C}\left(1922^{\circ} \mathrm{F}\right)$, all of the cold-worked specimens from nose, tail, and center of the extrusion exhibits a fully recrystallized structure of fairly equiaxed grains of ASTM grain size nos, 6-8.

To summarize the above results, Pt-3008 sheets fabricated from our first scale-up ingot with either 40 or $50 \%$ final cold rolling will 


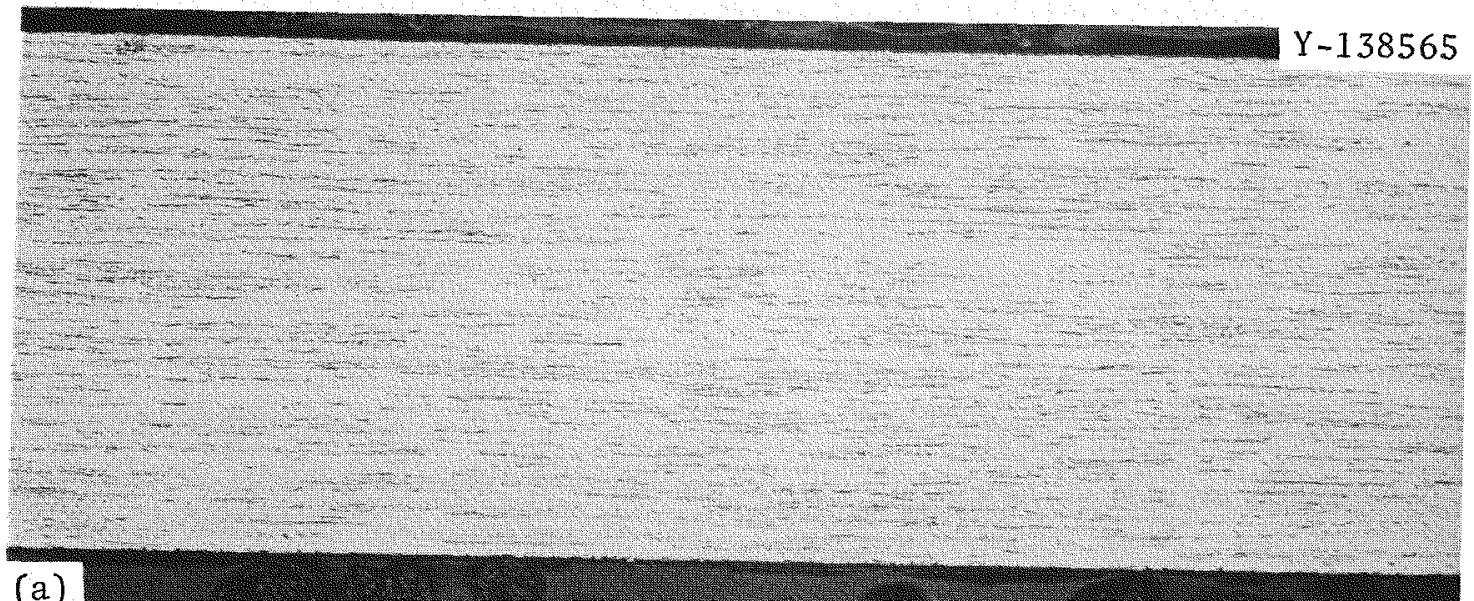

(a)
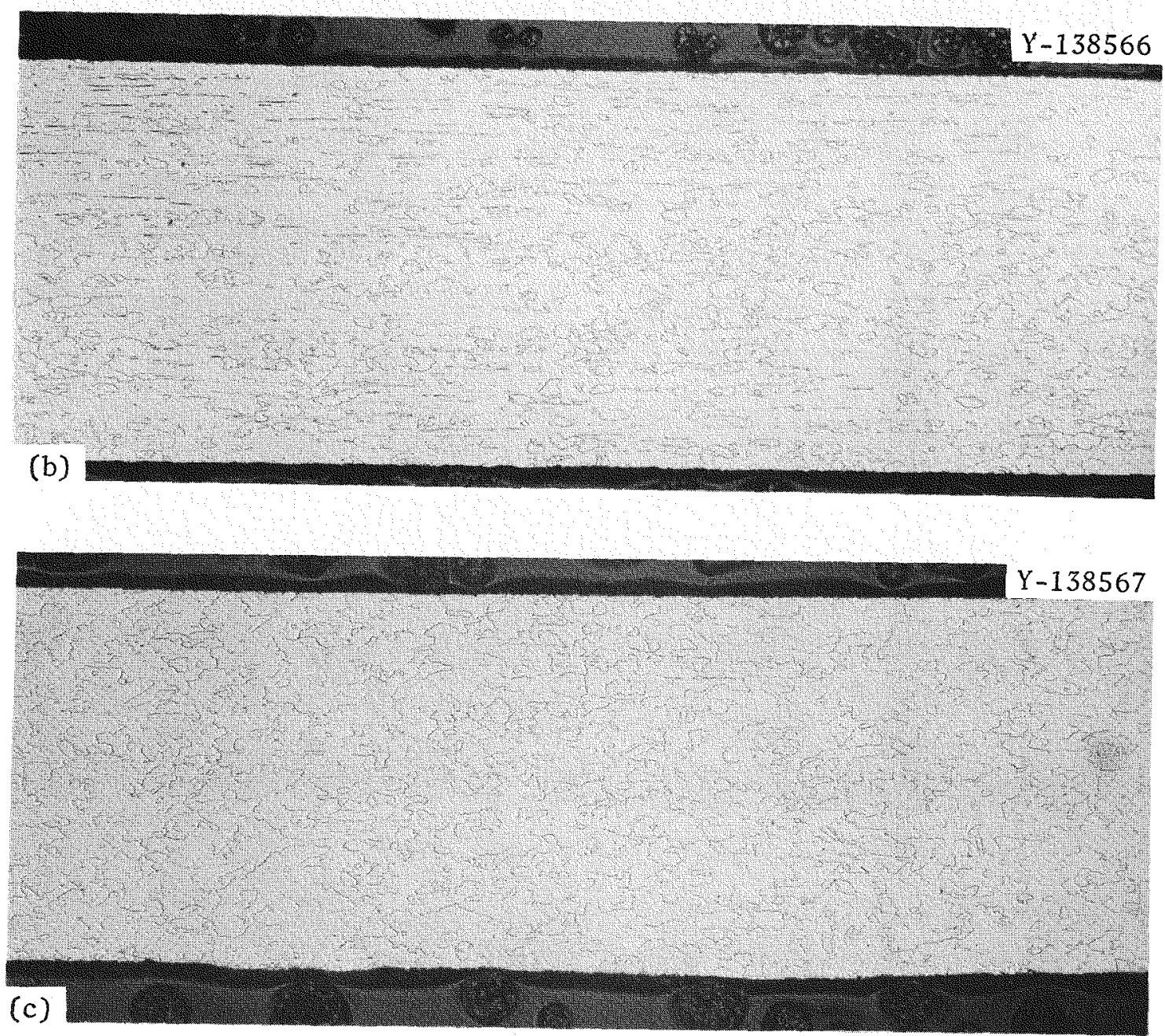

Fig. 1.4. Polished and Etched Specimens of Pt-3008 Sheets from Central Portion of Extruded Bar after Being Reduced Approximately $40 \%$ in Thickness at Room Temperature and then Heat Treated $1 \mathrm{hr}$ in Vacuum: (a) $950^{\circ} \mathrm{C}$ $\left(1742^{\circ} \mathrm{F}\right)$; (b) $1000^{\circ} \mathrm{C}\left(1832^{\circ} \mathrm{F}\right)$; and (c) $1050^{\circ} \mathrm{C}\left(1922^{\circ} \mathrm{F}\right) \cdot 100 \times$. 
recrystallize fully when heated in vacuum $1 \mathrm{hr}$ at temperatures greater than or equal to $1050^{\circ} \mathrm{C}\left(1922^{\circ} \mathrm{F}\right)$. At lower stress-relieving temperatures of less than or equal to $950^{\circ} \mathrm{C}\left(1742^{\circ} \mathrm{F}\right)$ for $1 \mathrm{hr}$ in vacuum, these sheets should retain their fibrous cold-worked structure.

Fabrication of additional Pt-3008 sheets for LASL and ORNL qualification studies and test hardware continues. The first scale-up ingot [approximately $60 \mathrm{~mm}$ (2 $3 / 8 \mathrm{in.}$ ) in diameter, weighting $6 \mathrm{~kg}$ (13 1b)] was canned in a 4-in.-diam heavy-wall molybdenum shell and was extruded successfully (along with the molybdenum leader and TZM tail) into an oval-shaped bar. The second scale-up ingot (approximately $73 \mathrm{~mm}(27 / 8 \mathrm{in}$.) in diameter, weighing $8.4 \mathrm{~kg}(18.5 \mathrm{lb})$ ] was coated with a thin layer of plasma-sprayed molybdenum to minimize ovality and increase yield. However, this second ingot did not extrude and developed numerous cracks when the molybdenum leader failed to extrude due to high hardness. Similar conditions were used for both extrusions; however, the second ingot was probably at lower temperature during upset due to less mass of molybdenum around the Pt-3008. The second ingot has been remelted for subsequent extrusion in a fully annealed heavy-wall molybdenum container.

A potential and perhaps more economical method of fabrication Pt-3008 sheet than extrusion is rolling an induction-melted casting. To investigate the feasibility of this method and to provide a commercial source for the alloy, a commercial company is casting a $19-\mathrm{mm}-(0.75-\mathrm{in}$ - -) thick ingot from $5.6 \mathrm{~kg}$ (12.4 lb) of ORNL's prealloyed material. This casting should be received for evaluation and rolling studies during July 1976.

\subsubsection{Characterization of $\mathrm{Pt}-3008$ Scale-Up Heat $-\mathrm{H}$. Inouye}

Sections from the nose, center, and tail of an extruded sheet bar of Pt-3008 were rolled to $0.5-\mathrm{mm}-(0.020-\mathrm{in} .-)$ thick sheet and tensile tested to determine whether the properties depended on the location. Specimens with their gage section parallel and transverse to the rolling direction were also tested to determine if any directionality of properties existed. The results listed in Table 1.3 show that the sheet prepared from the center of the extrusion [sheet El(4B)] tends to have a slightly higher yield strength and lower ductility than either the nose or tail sections at 760 
Table 1.3. Effect of Specimen Location and Orientation on Tensile Properties of Pt-3008 Sheet ${ }^{\mathrm{a}}$

\begin{tabular}{|c|c|c|c|c|}
\hline \multicolumn{2}{|c|}{ Specimen Description } & \multicolumn{2}{|c|}{ Strength, MPa(ksi) } & \multirow[b]{2}{*}{$\begin{array}{c}\text { Elongation } \\
\left(\frac{0}{0}\right)\end{array}$} \\
\hline $\begin{array}{l}\text { Location in } \\
\text { Extrusion }\end{array}$ & $\begin{array}{l}\text { Orientation } \\
\text { to Rolling } \\
\text { Direction }\end{array}$ & $\begin{array}{l}\text { U1timate } \\
\text { Tensile }\end{array}$ & $\begin{array}{l}0.2 \% \\
\text { Yield }\end{array}$ & \\
\hline \multicolumn{5}{|c|}{$25^{\circ} \mathrm{C}$} \\
\hline Nose & Parallel & $601.5(87.3)$ & $340.0(49.2)$ & 11.0 \\
\hline Nose & Transverse & $640.8(91.8)$ & $341.7(49.6)$ & 12.6 \\
\hline Center & Para11e1 & $695.2(100.9)$ & $348.6(50.6)$ & 16.4 \\
\hline Tail & Para11e1 & $646.3(93.8)$ & $318.3(46.2)$ & 16.0 \\
\hline Tail & Transverse & $724.8(105.2)$ & $326.6(47.4)$ & 23.2 \\
\hline \multicolumn{5}{|c|}{$760^{\circ} \mathrm{C}$} \\
\hline Nose & Paralle1 & $549.3(79.7)$ & $161.2(23.4)$ & 34.6 \\
\hline Nose & Transverse & $569.8(82.7)$ & $168.8(24.5)$ & 35.2 \\
\hline Center & Para11e1 & $547.8(79.5)$ & $196.4(28.5)$ & 28.2 \\
\hline Tail & Parallel & $551.2(80.0)$ & $148.8(21.6)$ & 36.2 \\
\hline Tail & Transverse & $534.0(77.5)$ & $151.6(22.0)$ & 35.4 \\
\hline \multicolumn{5}{|c|}{$1093^{\circ} \mathrm{C}$} \\
\hline Nose & Parallel & $261.8(38.0)$ & $128.8(18.7)$ & 20.0 \\
\hline Nose & Transverse & $291.5(42.3)$ & $127.5(18.5)$ & 36.2 \\
\hline Center & Para11e1 & $241.8(35.1)$ & $141.3(20.5)$ & 14.6 \\
\hline Tail & Paral1e1 & $277.7(40.3)$ & $130.2(18.9)$ & 36.0 \\
\hline Tail & Transverse & $281.1(40.8)$ & $128.8(18.7)$ & 40.8 \\
\hline
\end{tabular}

$a_{\text {Heat }}$ E1. Consumable arc melt, extruded to sheet bar and rolled to 0.020 -in.- thick sheet. Annealed $1 \mathrm{hr}$ at $1200^{\circ} \mathrm{C}$.

and $1093^{\circ} \mathrm{C}$. The tensile properties paralle1 or transverse to the rolling direction were essentially the same. The observed scatter in the properties is similar to that observed in the small drop-cast ingots.

\subsubsection{Welding of Pt-3008 Alloy - G. M. Goodwin}

Testing of electron-beam weldments in sheet from the first scale-up heat [sheet E1(5)] is continuing. To date, fifteen tensile tests have been performed, all at $20^{\circ} \mathrm{C}$, as noted in Table 1.4 .

Base metal stress relieved $1 \mathrm{hr}$ at $850^{\circ} \mathrm{c}$ shows high strength at room temperature with $12 \%$ total elongation. Annealing $1 \mathrm{hr}$ at $1200^{\circ} \mathrm{C}$ causes full recrystallization with the usual reductions in strength. Yield 
Table 1.4. Room-Temperature Tensile Properties of Pt-3008 Electron-Beam Weldments ${ }^{a}$

\begin{tabular}{|c|c|c|c|c|c|}
\hline \multirow{2}{*}{$\begin{array}{c}\text { Specimen } \\
\text { Designation }\end{array}$} & \multirow[b]{2}{*}{$\begin{array}{l}\text { Specimen } \\
\text { Type }^{b}\end{array}$} & \multicolumn{2}{|c|}{ Strength, MPa(ksi) } & \multirow{2}{*}{$\begin{array}{c}\text { Total } \\
\text { Elongation } \\
(\%)\end{array}$} & \multirow[b]{2}{*}{$\begin{array}{l}\text { Fracture } \\
\text { Location }\end{array}$} \\
\hline & & $\begin{array}{l}0.2 \% \\
\text { Offset } \\
\text { Yield }\end{array}$ & U1timate & & \\
\hline $\operatorname{EI}(5)-1$ & B & $1149.4(166.7)$ & $1393.5(202.1)$ & 12.0 & - \\
\hline $\mathrm{E} 1(5)-2$ & B & $1149.4(166.7)$ & $1393.5(202.1)$ & 12.0 & - \\
\hline $\operatorname{EI}(5)-5$ & $B-R$ & $317.2(46.0)$ & $606.8(88.0)$ & $c$ & c \\
\hline E1 (5) -13 & $B-R$ & $330.4(47.9)$ & $474.0(68.8)$ & 5.0 & - \\
\hline E1(5) -14 & $B-R$ & $330.4(47.9)$ & $502.8(72.9)$ & 6.5 & - \\
\hline$E 1(5)-3$ & $W$ & $430.9(62.5)$ & $430.9(62.5)$ & 2.0 & weld \\
\hline $\mathrm{E} 1(5)-4$ & W & $459.7(66.7)$ & $459.7(66.7)$ & 2.0 & weld \\
\hline$E 1(5)-6$ & W-P & $331.0(48.0)$ & $413.7(60.0)$ & 3.2 & weld \\
\hline E1 (5) -15 & $W-P$ & $316.0(45.8)$ & $402.2(58.3)$ & 4.0 & weld \\
\hline $\operatorname{E} 1(5)-7$ & $\mathrm{R}-\mathrm{W}$ & $303.4(44.0)$ & $386.1(56.0)$ & 2.0 & base metal \\
\hline $\mathrm{EI}(5)-8$ & $R-W$ & $275.8(40.0)$ & $399.9(58.0)$ & 2.0 & base metal \\
\hline$E 1(5)-9$ & $R-W$ & $399.9(58.0)$ & $399.9(58.0)$ & 2.0 & weld \\
\hline $\mathrm{E} 1(5)-10$ & $R-W$ & $317.2(46.0)$ & $317.2(46.0)$ & 2.0 & weld \\
\hline E1(5)-11 & $R-W-P$ & $303.4(44.0)$ & $455.1(66.0)$ & 4.0 & weld \\
\hline $\mathrm{E} 1(5)-12$ & $R-W-P$ & $303.4(44.0)$ & $427.5(62.0)$ & 4.0 & we1d \\
\hline
\end{tabular}

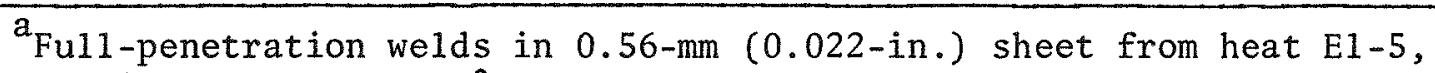
stress relieved $1 \mathrm{hr}$ at $850^{\circ} \mathrm{C}$ prior to welding. All tests performed at $20^{\circ} \mathrm{C}$. $\mathrm{b}_{\mathrm{B}}=$ base metal; $\mathrm{R}=$ reannealed $1 \mathrm{hr}$ at $1200^{\circ} \mathrm{C}$ prior to welding; $\mathrm{W}=$ transverse electron-beam weld; and $\mathrm{P}=$ post-weld heat treated $1 \mathrm{hr}$ at $1200^{\circ} \mathrm{C}$.

$c_{\text {Failed in specimen shoulder. }}$

strength drops by a factor of 3 to 4 ultimate strength by a factor of $21 / 2$; however, ductility is also decreased by a factor of 2 [specimens E1(5) $-5,-13$, and -14 vs E1(5) -1 and -2$]$.

Electron-beam welds in as-stress-relieved sheet [specimens E1(5)-3 and -4] show yield and ultimate strength values less than half that of stress-relieved base metal. Fracture occurs in the weld with low ductility ( $2 \%$ total elongation). Post-weld annealing $1 \mathrm{hr}$ at $1200^{\circ} \mathrm{C}$ gives the weldment strength properties comparable to annealed base metal and improves the ductility slightly [specimens E1(5)-6 and -15]. 
Welds in annealed sheet [specimens El(5)-7, -8, -9, and -10] show strength properties similar to annealed base metal and low ductility ( $2 \%$ total elongation). The results from specimens E1(5)-7 and -8 are suspect since fracture occurred in the shoulder radius, but the low ducti1ity is confirmed by specimens E1-9 and -10 .

Post-weld annealing of welds in annealed sheet for $1 \mathrm{hr}$ at $1200^{\circ} \mathrm{C}$ (E1-11 and -12) gives a slight ductility improvement as it did for welds in stress-relieved sheet.

\subsection{Ruthenium and Rhodium Alloys}

H. Inouye

This task is directed toward the identification and the characterization of suitable cladding materials for isotopic fuels with lower density and/or lower cost than iridium- or platinum-base alloys.

\subsubsection{Ruthenium-P1atinum Alloys}

Table 1.5 1ists the density, structure, and lattice constants of binary ruthenium-platinum alloys containing less than 20 at. $\%$ Pt. The closepacked hexagonal $(\mathrm{cph})$ structure of ruthenium persists in alloys with 15 at. \% Pt or 1ess; however, a small amount of a face-centered cubic (fcc) phase was identified in the 20 at. $\%$ Pt alloy. This fcc phase with a lattice parameter of $3.86 \AA$ is assumed to be a solid solution of ruthenium and platinum. Since the 20 at. $\%$ Pt alloy severely cracked on hot rolling, it appears that fabricable alloys in this system will require more platinum; however, as Table 1.5 shows, platinum increases the density.

\subsubsection{Rhodium Alloys}

An arc-drop-cast ingot of rhodium was readily hot rolled to $0.5-\mathrm{mm}$ (0.020-in.-) thick sheet. The final rolling temperature of $1000^{\circ} \mathrm{C}$ resulted in a sheet too brittle to prepare test specimens at room temperature. Rerolling the sheet at $800^{\circ} \mathrm{C}$ restored some ductility and may permit specimen preparation. In contrast, a $\mathrm{Rh}-20 \% \mathrm{Ru}$ alloy (also rolled to sheet at $1000^{\circ} \mathrm{C}$ ) was bent $25 \mathrm{deg}$ over a $2 \mathrm{~T}$ bend radius at room temperature. As 
Table 1.5. Density and X-Ray Data for Ruthenium-Platinum Alloys Annealed $1 \mathrm{hr}$ at $1600^{\circ} \mathrm{C}$

\begin{tabular}{cccccc}
\hline $\begin{array}{c}\text { Composition } \\
(\mathrm{at.} \% \mathrm{Pt})\end{array}$ & $\begin{array}{c}\text { Density } \\
\left(\mathrm{g} / \mathrm{cm}^{3}\right)\end{array}$ & Structure & \multicolumn{3}{c}{ Lattice Constants, } \\
\cline { 5 - 7 } & 12.45 & $\mathrm{cph}$ & 2.6987 & 4.2730 & 1.5834 \\
5 & 12.78 & $\mathrm{cph}$ & 2.7090 & 4.2916 & 1.5842 \\
10 & 13.27 & $\mathrm{cph}$ & 2.7124 & 4.2989 & 1.5849 \\
15 & 13.76 & $\mathrm{cph}$ & 2.7140 & 4.3065 & 1.5868 \\
20 & 14.20 & $\mathrm{cph}, \mathrm{fcc}^{\mathrm{a}}$ & 2.7163 & 4.3151 & 1.5886 \\
\hline $\mathrm{a}_{\text {Three weak peaks, } \alpha_{\mathrm{o}}=3.86 \AA .}$ & & & &
\end{tabular}

shown in Table 1.6, this bend angle can be increased to 78 deg after annealing $1 \mathrm{hr}$ at $900^{\circ} \mathrm{C}$.

The rhodium-ruthenium diagram has recently been reported to be a peritectic-type system with a narrow two-phase region between $40-60$ at. $\%{ }^{5}$ Alloys containing over 20 at. $\% \mathrm{Ru}$ could, therefore, be fabricable.

Table 1.6. Effect of Heat Treatment on $2 \mathrm{~T}$ Bend Angles of $\mathrm{Rh}-20 \% \mathrm{Ru}$ at Room Temperature

\begin{tabular}{cc}
$\begin{array}{c}\text { 1-hr Heat Treatment } \\
\text { at }\left({ }^{\circ} \mathrm{C}\right)\end{array}$ & $\begin{array}{c}\text { Bend Angle } \\
\text { (deg) }\end{array}$ \\
\hline As-rolled at $1000^{\circ} \mathrm{C}$ & 25 \\
400 & 48 \\
600 & 51 \\
700 & 57 \\
800 & 62 \\
900 & 78 \\
1000 & 63 \\
1100 & 35 \\
1300 & 24 \\
\hline
\end{tabular}




\subsection{References}

1. F. A. Shunk, Constitution of Binary AZZoys, Second Supplement, McGraw Hi11 Book Company, New York (1969), p. 466.

2. A. C. Schaffhauser, Isotopic Power Materials Development Quart. Progr. Rep. Mar. 31, 1976, ORNL/TM-5482.

3. R. G. Donne11y, Isotopic Power Materials DeveZopment Ann. Progr. Rep. June 30, 1975, ORNL-TM-5116, p. 2.

4. A. C. Schaffhauser, Isotopic Power Materials Development Quart. Progr. Rep. Mar. 31, 1976, ORNL/TM-5482, pp. 13-20.

5. E. M. Savitskii, V. P. Polyakova, N. R. Rosman, "Interaction of Ruthenium with Platinum Group Metals," AZZ-Union Conference on the General Characteristics in the Construction of Structural Diagrams of Metallic Systems, 5th, Moscow (1971), pp. 47-9. 
Blank 
2. PHYSICAL AND MECHANICAL METALLURGY OF HEAT-SOURCE CONTAINMENT MATERIALS*

\subsection{Introduction}

The high reliability in long-term unattended operation, high operating temperatures, and potentially severe accident conditions of isotope-fueled energy conversion systems require that materials for critical components be exclusively tested and that the limitations on their use be defined. The objective of this program is to evaluate and determine the suitability and limitations of such materials. To accomplish this objective, we have concentrated our efforts on the evaluation of materials under the most severe potential accident conditions (e.g., high-velocity reentry and impact of an isotope heat source from space after long-term operation). The potential degradation of material properties from environmental and impurity effects is being evaluated along with studies on the mechanisms controlling the properties of materials of interest. In addition, special projects and consulting on materials problems for isotope-fueled energy conversion systems are performed as requested by ERDA.

\subsection{Characterization of Impact Properties}

\subsubsection{Impact Properties of Iridium Alloys - C. T. Liu}

2.2.1.1 DOP-4 Dopant Effect. - Tensile specimens of DOP-13, -15 , and -16 alloys were heat treated at 1500 and $1800^{\circ} \mathrm{C}$ and then impact tested at $1350^{\circ} \mathrm{C}$ at a velocity of $85 \mathrm{~m} / \mathrm{sec}$ (280 fps) to isolate the effects of DOP -4 dopants. The impact results are presented in Table 2.1 and are compared with DOP-4 alloy and undoped WG. The grain size of the impact specimens is also presented in Table 2.1. At the three heat-treatment conditions shown in Table 2.1, the DOP-13 alloy, doped with $30 \mathrm{ppm}$ Th and $40 \mathrm{ppm} \mathrm{A1,} \mathrm{consist-}$ ently showed finer grain structure and much better impact properties, as compared with the DOP-15 alloy doped with $30 \mathrm{ppm}$ Th and $80 \mathrm{ppm}$ Fe. This indicates that aluminum, in addition to thorium, is effective in improving

${ }^{*}$ Progress on work performed under Activity No. KJ 300102 3, 189a No. 00002 . 

Table 2.1. Tensile Impact Properties of $\operatorname{Ir}-0.3 \%$ W Doped with DOP-4
Series of Dopants

\begin{tabular}{|c|c|c|c|c|c|}
\hline $\begin{array}{c}\text { Alloy } \\
\text { Specimen }\end{array}$ & $\begin{array}{c}\text { Nominal Dopant } \\
\text { Concentration } \\
\text { (ppm) }\end{array}$ & $\begin{array}{l}\text { Grain } \\
\text { Size }\end{array}$ & $\begin{array}{c}\text { Elongation } \\
\left(\begin{array}{l}0 \\
0\end{array}\right)\end{array}$ & $\begin{array}{c}\text { Reduction } \\
\text { of Area } \\
(\%)\end{array}$ & Fracture Mode ${ }^{c}$ \\
\hline \multicolumn{6}{|c|}{ Annealed 1 hr at $1500^{\circ} \mathrm{C}$} \\
\hline$W G-202$ & None & 10.7 & 12.6 & 28 & Mainly GBS \\
\hline DOP-15 & $80 \mathrm{Fe}, 30 \mathrm{Th}$ & 15.6 & 31.2 & 92 & $\mathrm{DR}$ \\
\hline DOP -13 & $40 \mathrm{Al}, 30 \mathrm{Th}$ & 23.9 & 40.4 & 95 & $\mathrm{DR}$ \\
\hline DOP-4 & $\begin{array}{l}40 \mathrm{Al}, 80 \mathrm{Fe}, 30 \mathrm{Th}, \\
16 \mathrm{Ni}, 75 \mathrm{Rh}\end{array}$ & 19.2 & 37.6 & 94 & $\mathrm{DR}$ \\
\hline \multicolumn{6}{|c|}{ Annealed $19 \mathrm{hr}$ at $1500^{\circ} \mathrm{C}$} \\
\hline WG-202 & None & 5.8 & 10.7 & 24 & Mainly GBS \\
\hline DOP-15 & $80 \mathrm{Fe}, 30 \mathrm{Th}$ & 8.1 & 15.1 & 39 & TF and GBS \\
\hline DOP -13 & $40 \mathrm{Al}, 30 \mathrm{Th}$ & 12.2 & 27.2 & 64 & $\mathrm{TF}$ and $\mathrm{DR}$ \\
\hline DOP-16 & $40 \mathrm{Al}, 80 \mathrm{Fe}, 30 \mathrm{Th}$ & 10.3 & 26.6 & 56 & $\mathrm{TF}$ and $\mathrm{DR}$ \\
\hline \multirow[t]{2}{*}{ DOP -4} & $\begin{array}{l}40 \mathrm{Al}, 80 \mathrm{Fe}, 30 \mathrm{Th}, \\
16 \mathrm{Ni}, 75 \mathrm{Rh}\end{array}$ & 9.9 & 26.8 & 60 & $\mathrm{TF}$ and $\mathrm{DR}$ \\
\hline & Annealed $1 \mathrm{hr}$ at 1 & $500^{\circ} \mathrm{C}+$ & $\mathrm{hr}$ at $1800^{\circ}$ & $+1 \mathrm{hr}$ at & $500^{\circ} \mathrm{C}$ \\
\hline WG-202 & None & $2.4^{\mathrm{d}}$ & $3.4^{\mathrm{d}}$ & $6^{\mathrm{d}}$ & Completely GBS \\
\hline DOP-15 & $80 \mathrm{Fe}, 30 \mathrm{Th}$ & - & 9.9 & 20 & Mainly GBS \\
\hline DOP -13 & $40 \mathrm{Al}, 30 \mathrm{Th}$ & 5.7 & 15.7 & 32 & GBS and TF \\
\hline DOP-16 & $40 \mathrm{Al}, 80 \mathrm{Fe}, 30 \mathrm{Th}$ & - & 10.7 & 23 & Mainly GBS \\
\hline DOP-4 & $\begin{array}{l}40 \mathrm{Al}, 80 \mathrm{Fe}, 30 \mathrm{Th}, \\
16 \mathrm{Ni}, 75 \mathrm{Rh}\end{array}$ & 3.8 & 11.0 & 19 & Mainly GBS \\
\hline
\end{tabular}

Impact condition: $1350^{\circ} \mathrm{C}$ and $85 \mathrm{~m} / \mathrm{sec}(280 \mathrm{fps})$.

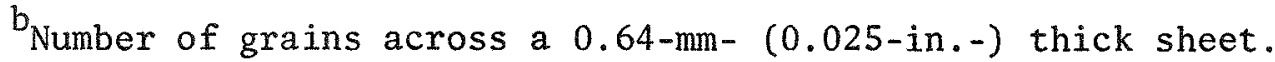

${ }^{c_{G B S}}=$ grain-boundary separation; $\mathrm{TF}=$ transgranular fracture; $\mathrm{Ma}=$ major fraction; $\mathrm{Mi}=$ minor fraction; and $\mathrm{DR}=$ ductile rupture.

$\mathrm{d}_{\text {Average of two tests. }}$

the impact properties of $\operatorname{Ir}-0.3 \% \mathrm{~W}$ alloy. The impact properties of DOP-16 and DOP-4 are about the same, indicating that nickel and rhodium have no major effect on improving impact properties of $\operatorname{Ir}-0.3 \% \mathrm{~W}$. The DOP-13 a1loy, which had $15.7 \%$ elongation * after a severe heat treatment at $1500-1800^{\circ} \mathrm{C}$,

*With this ductility, the DOP-13 alloy may survive the MHW/FSA-type impact test. 
has the best impact properties among these alloys. Thus, our isolation of the DOP-4 dopants leads to the conclusion that aluminum, in addition to thorium, improves the impact behavior of $\mathrm{Ir}-0.3 \% \mathrm{~W}$.

2.2.1.2 Thorium Concentration Effect. - The tensile impact properties of $\operatorname{Ir}-0.3 \% \mathrm{~W}$ alloys doped with $500 \mathrm{ppm}$ Th (DOP-21) and $50 \mathrm{ppm}$ Th (WTh-1) were determined after heat treatments at $1500-1800^{\circ} \mathrm{C}$. All the heat-treated specimens were impacted at a velocity of $85 \mathrm{~m} / \mathrm{sec}(280 \mathrm{fps})$ at $1350^{\circ} \mathrm{C}$. The results are presented in Table 2.2 and are compared with the other thoriumdoped alloys reported previously. ${ }^{1}$ The impact elongation is also plotted as a function of thorium content in Fig. 2.1. After a heat treatment of $1 \mathrm{hr}$ at $1500^{\circ} \mathrm{C}$, the impact elongation increases almost linearly with thorium content in the alloy to $100 \mathrm{ppm}$, but it becomes less effective above this level (Fig. 2.1). The alloys showed ductile rupture with more than $87 \%$ reduction of area after being doped with $50 \mathrm{ppm}$ Th or more. After a heat treatment of $19 \mathrm{hr}$ at $1500^{\circ} \mathrm{C}$, the impact elongation and reduction of area also increase with thorium content and become less sensitive to thorium content in the range 200-1000 ppm. After a severe heat treatment at 1500 and $1800^{\circ} \mathrm{C}$, the alloys doped with $200-1000 \mathrm{ppm}$ Th had $25.2-26.6 \%$ elongation and $71-83 \%$ reduction of area and fractured by ductile rupture and transgranular fracture, which are distinctly better than the alloys doped with lower levels of thorium. Thus, the DOP-14 and -21 and WTh-2 are most resistant to degradation due to several heat treatments. The plot in Fig. 2.1 shows that the DOP-21 alloy, doped with $500 \mathrm{ppm} T \mathrm{Th}$, is slightly superior to DOP-14 and WTh-2 under a11 heat-treatment conditions.

\subsubsection{Impact Temperature Effect. - The thorium-doped alloys were} impacted at $950^{\circ} \mathrm{C}$ to show the impact temperature effect. A11 the specimens were heat treated $1 \mathrm{hr}$ at $1500^{\circ} \mathrm{C}$ and tested at a velocity of $85 \mathrm{~m} / \mathrm{sec}$ (280 fps). The impact results are presented in Table 2.3. The impact elongation and reduction of area at $950^{\circ} \mathrm{C}$ increase with thorium content to $200 \mathrm{ppm}$ and then decrease. This variation in impact ductility cannot be simply correlated with grain size as shown in Table 2.3. However, a correlation seems to exist between the impact properties at $950^{\circ} \mathrm{C}$ and the fracture behavior ${ }^{1}$ at a slow strain rate at $650^{\circ} \mathrm{C}$. The DOP-14 and -22 alloys, 
Table 2.2 Effects of Thorium Content and Heat Treatment on Tensile Impact Properties of $\mathrm{Ir}-0.3 \% \mathrm{~W}$ Sheet Specimens

Tested at $85 \mathrm{~m} / \mathrm{sec}(280 \mathrm{fps})$ and $1350^{\circ} \mathrm{C}$

\begin{tabular}{|c|c|c|c|c|c|}
\hline $\begin{array}{l}\text { A1loy } \\
\text { Number }\end{array}$ & $\begin{array}{l}\text { Thorium } \\
\text { Content } \\
\text { (ppm) }\end{array}$ & $\begin{array}{l}\text { Grain } \\
\text { Size }\end{array}$ & $\begin{array}{c}\text { Elongation } \\
\left(\frac{0}{0}\right)\end{array}$ & $\begin{array}{c}\text { Reduction } \\
\text { of Area } \\
(\%)\end{array}$ & Fracture Mode ${ }^{b}$ \\
\hline \multicolumn{6}{|c|}{ Annealed $1 \mathrm{hr}$ at $1500^{\circ} \mathrm{C}$} \\
\hline WG -202 & 0 & 10.7 & 12.6 & 28 & Main1y GBS \\
\hline WTh-1 & 50 & 20.9 & 25.5 & 89 & $\mathrm{DR}$ \\
\hline DOP-22 & 100 & 19.3 & 38.2 & 87 & $\mathrm{DR}$ \\
\hline $\mathrm{DOP}-14$ & 200 & 25.3 & 37.9 & 92 & $\mathrm{DR}$ \\
\hline DOP-21 & 500 & 27.7 & 41.7 & 93 & DR \\
\hline WTh -2 & 1000 & 27.3 & 39.4 & 87 & DR \\
\hline \multicolumn{6}{|c|}{ Annealed $19 \mathrm{hr}$ at $1500^{\circ} \mathrm{C}$} \\
\hline WG-202 & 0 & 5.8 & 10.9 & 23 & Mainly GBS \\
\hline WG-202 & 0 & 5.8 & 10.5 & 24 & Mainly GBS \\
\hline WTh-1 & 50 & 9.5 & 14.7 & 34 & Mainly GBS \\
\hline DOP-22 & 100 & 10.8 & 23.8 & 50 & $\mathrm{TF}$ \\
\hline DOP-14 & 200 & 15.0 & 28.9 & 84 & DR \\
\hline DOP-14 & 200 & 15.0 & 29.1 & 90 & DR \\
\hline DOP -21 & 500 & 22.6 & 33.8 & 91 & DR \\
\hline WTh-2 & 1000 & 21.8 & c & 79 & DR \\
\hline WTh-2 & 1000 & 21.8 & 29.0 & 87 & DR \\
\hline \multicolumn{6}{|c|}{ Annealed $1 \mathrm{hr}$ at $1500^{\circ} \mathrm{C}+1 \mathrm{hr}$ at $1800^{\circ} \mathrm{C}+1 \mathrm{hr}$ at $1500^{\circ} \mathrm{C}$} \\
\hline WG-202 & 0 & 2.4 & 2.2 & 7 & Completely GBS \\
\hline WG-202 & 0 & 2.4 & 4.6 & 5 & Completely GBS \\
\hline WTh-1 & 50 & 4.2 & 7.2 & 17 & Mainly GBS \\
\hline DOP-22 & 100 & 6.5 & 14.1 & 27 & Mainly GBS \\
\hline DOP-I 4 & 200 & 12.0 & 25.2 & 71 & $\mathrm{DR}$ and $\mathrm{TF}$ \\
\hline DOP-21 & 500 & 15.8 & 26.6 & 83 & $\mathrm{DR}$ and $\mathrm{TF}$ \\
\hline WTh-2 & 1000 & 14.9 & 25.4 & 73 & $\mathrm{DR}$ and $\mathrm{TF}$ \\
\hline
\end{tabular}

a Number of grains across a $0.64-\mathrm{mm}-(0.025-\mathrm{in} .-)$ thick sheet.

${ }_{\mathrm{GBS}}=$ grain-boundary separation; $\mathrm{TF}=$ transgranular fracture; $\mathrm{Ma}=$ major fraction; $M i=$ minor fraction; and $D R=$ ductile rupture.

${ }^{c}$ Not able to measure; gage section destroyed. 


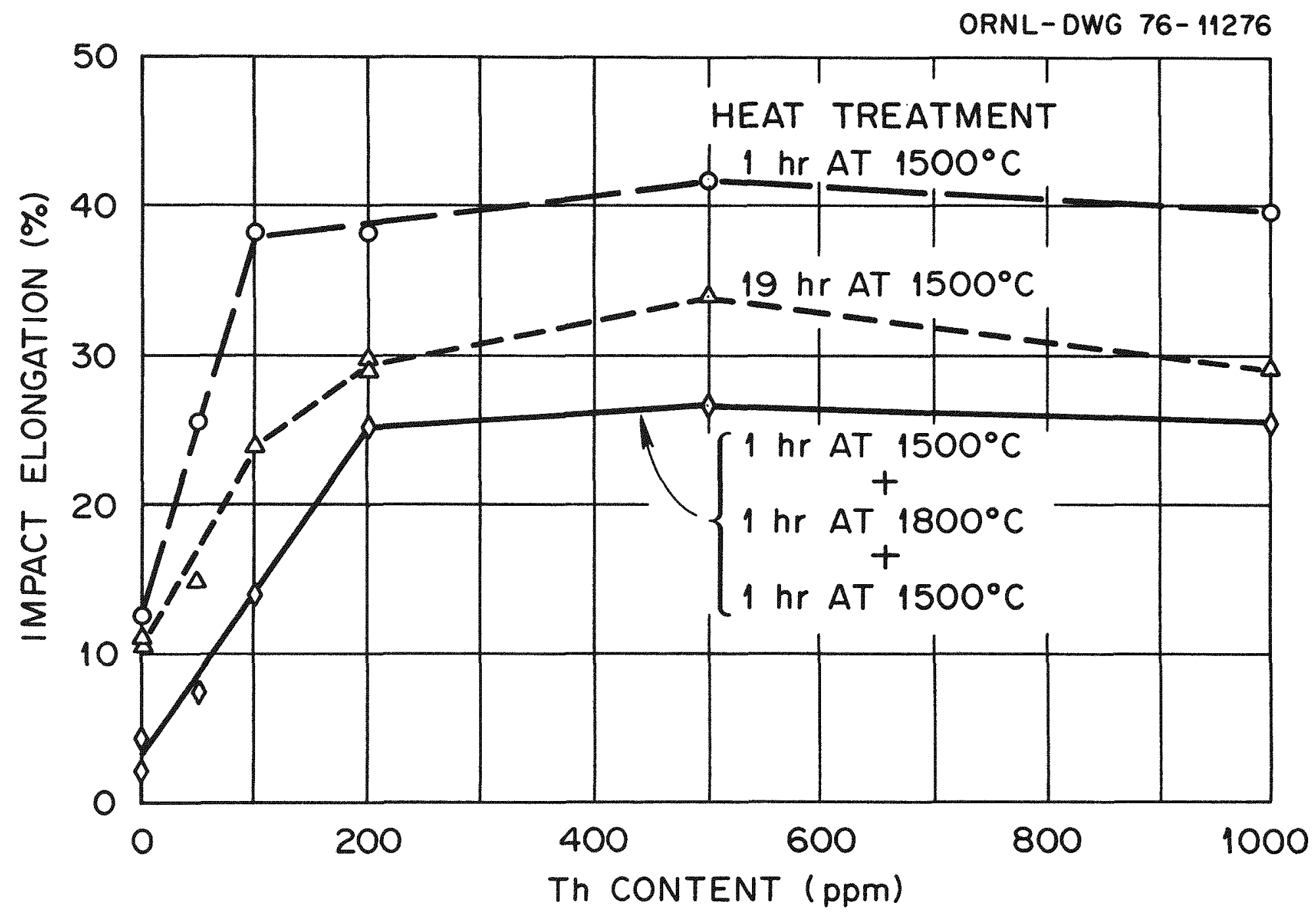

Fig. 2.1. Impact Elongation of the Thorium-Doped $\mathrm{Ir}-0.3 \% \mathrm{~W}$ Alloys Tested at $1350^{\circ} \mathrm{C}$ and $85 \mathrm{~m} / \mathrm{sec}$ (280 fps). 
Table 2.3. Tensile Impact Properties of Undoped and Thorium-Doped Ir $-0.3 \% \mathrm{~W}$ Sheet Specimens ${ }^{\mathrm{a}}$ Tested at $950^{\circ} \mathrm{C}$ and $85 \mathrm{~m} / \mathrm{sec}(280 \mathrm{fps})$

\begin{tabular}{|c|c|c|c|c|c|}
\hline $\begin{array}{l}\text { Alloy } \\
\text { Number }\end{array}$ & $\begin{array}{l}\text { Dopants } \\
\text { (ppm) }\end{array}$ & $\begin{array}{l}\text { Grain } \\
\text { Size }\end{array}$ & $\begin{array}{c}\text { Elongation } \\
(\%)\end{array}$ & $\begin{array}{c}\text { Reduction } \\
\text { of Area } \\
(\%)\end{array}$ & Fracture Mode $\mathrm{c}^{\mathrm{c}}$ \\
\hline WG & None & 10.7 & 4.5 & 12 & Mainly GBS \\
\hline WTh-1 & $50 \mathrm{Th}$ & 20.9 & 6.2 & 13 & Mainly GBS \\
\hline DOP -22 & $100 \mathrm{Th}$ & 19.3 & 11.4 & 23 & GBS (Ma) and TF (Mi) \\
\hline DOP-14 & $200 \mathrm{Th}$ & 25.3 & 14.5 & 36 & TF and GBS \\
\hline DOP-21 & $500 \mathrm{Th}$ & 27.7 & 7.1 & 17 & Mainly GBS \\
\hline
\end{tabular}

which showed mainly transgranular fracture at $650^{\circ} \mathrm{C}$, have the best impact properties at $950^{\circ} \mathrm{C}$. The DOP-21 and WTh-1 alloys, which showed mixed modes of grain-boundary separation and transgranular fracture at $650^{\circ} \mathrm{C}$, rank next. The undoped WG, which fractured mainly by grain-boundary separation at $650^{\circ} \mathrm{C}$, has the poorest impact ductility at $950^{\circ} \mathrm{C}$.

The impact elongation of DOP-14 is plotted as a function of test temperature in Fig. 2.2 and is compared with DOP-4 and -13 and undoped WG. The impact ductility of DOP-14 decreases with test temperature below $1200^{\circ} \mathrm{C}$; however, it remains better than the other alloys at all the test temperatures. The DOP-14 al1oy, which had $14.5 \%$ elongation and $36 \%$ reduction of area at $950^{\circ} \mathrm{C}$, appears to be most resistant to low-temperature impact among the doped alloys.

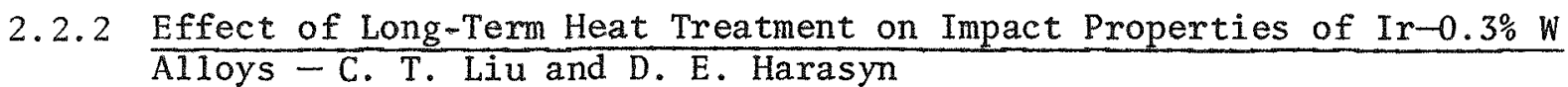
To study the effects of long-term heat treatments at the MHW fuel clad temperature on the physical and mechanical properties of $\operatorname{Ir}-0.3 \% \mathrm{~W}$ alloys, 


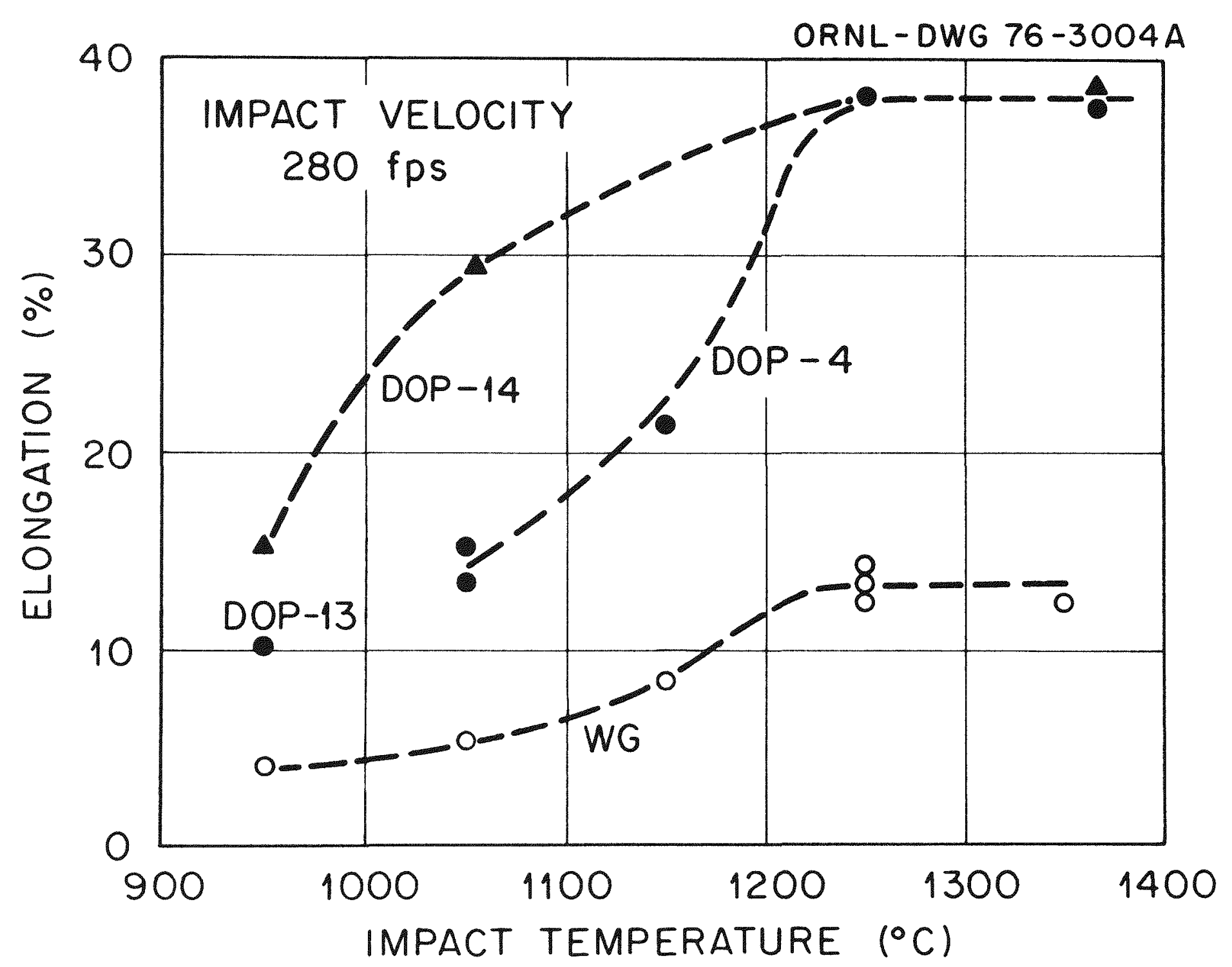

Fig. 2.2. Plot of Impact Elongation as a Function of Impact Temperature for $\operatorname{Ir}-0.3 \% \mathrm{~W}$ Alloys WG, DOP-4, DOP-13, and DOP-14. (All specimens heat treated $1 \mathrm{hr}$ at $1500^{\circ} \mathrm{C}$ prior to impact test.) 
WG (undoped) and HD (doped with DOP-4 dopants) specimens were annealed at $1330^{\circ} \mathrm{C}$ for various time periods and then impacted at $1350^{\circ} \mathrm{C}$ and $85 \mathrm{~m} / \mathrm{sec}$ (280 fps). Table 2.4 summarizes the impact data for the specimens annealed to $2000 \mathrm{hr}$. The impact elongation is also plotted as a logarithmic function of the annealing time in Fig. 2.3. The impact ductility of both alloys decreases with annealing time; this decrease is apparently due to grain growth as indicated in Table 2.4. The DOP-4 alloy had $24 \%$ elongation while WG had only $7.8 \%$ elongation after a 2000-hr anneal. Thus, DOP-4 is much more resistant to degradation due to long-term heat treatment at $1330^{\circ} \mathrm{C}$.

Table 2.4. Effect of Long-Term Anneal at $1330^{\circ} \mathrm{C}$ on the Impact Properties of $\mathrm{WG}^{\mathrm{a}}$ and $\mathrm{HD}^{\mathrm{b}}$ Specimens Tested at $85 \mathrm{~m} / \mathrm{sec}(280 \mathrm{fps})$ and $1350^{\circ} \mathrm{C}$

\begin{tabular}{|c|c|c|c|c|}
\hline Specimen & Size & $\begin{array}{c}\text { Impact } \\
\text { Elongation } \\
(\%)\end{array}$ & $\begin{array}{c}\text { Reduction } \\
\text { of Area } \\
(\%)\end{array}$ & $\begin{array}{l}\text { Fracture } \\
\text { Mode }\end{array}$ \\
\hline \multicolumn{5}{|c|}{$1^{1-h r}$ Annea ${ }^{\mathrm{e}}$} \\
\hline WG & 19.7 & 18.7 & 27 & GBS and TF \\
\hline DOP-4 & 26.9 & 36.0 & 94 & DR \\
\hline \multicolumn{5}{|c|}{ 200-hr Anneal } \\
\hline WG & - & 13.7 & 28 & Mainly GBS \\
\hline $\mathrm{HD}$ & - & - & - & - \\
\hline \multicolumn{5}{|c|}{ 480-hr Anneal } \\
\hline WG & 8.0 & 8.4 & 24 & Mainly GBS \\
\hline$H D$ & 21.5 & 26.5 & 90 & $\mathrm{DR}$ \\
\hline \multicolumn{5}{|c|}{ 980-hr Annea 1 } \\
\hline WG & 7.5 & 8.6 & 20 & Mainly GBS \\
\hline HD & 16.9 & 27.2 & 88 & $\mathrm{DR}$ \\
\hline \multicolumn{5}{|c|}{ 2000-hr Anneal } \\
\hline WG & 4.7 & 7.8 & 19 & Mainly GBS \\
\hline $\mathrm{HD}$ & 13.3 & 24.0 & 61 & Mainly TF \\
\hline \multicolumn{5}{|c|}{${ }^{\mathrm{a}}$ Undoped $\operatorname{Ir}-0.3 \% \mathrm{~W}$ specimens. } \\
\hline
\end{tabular}




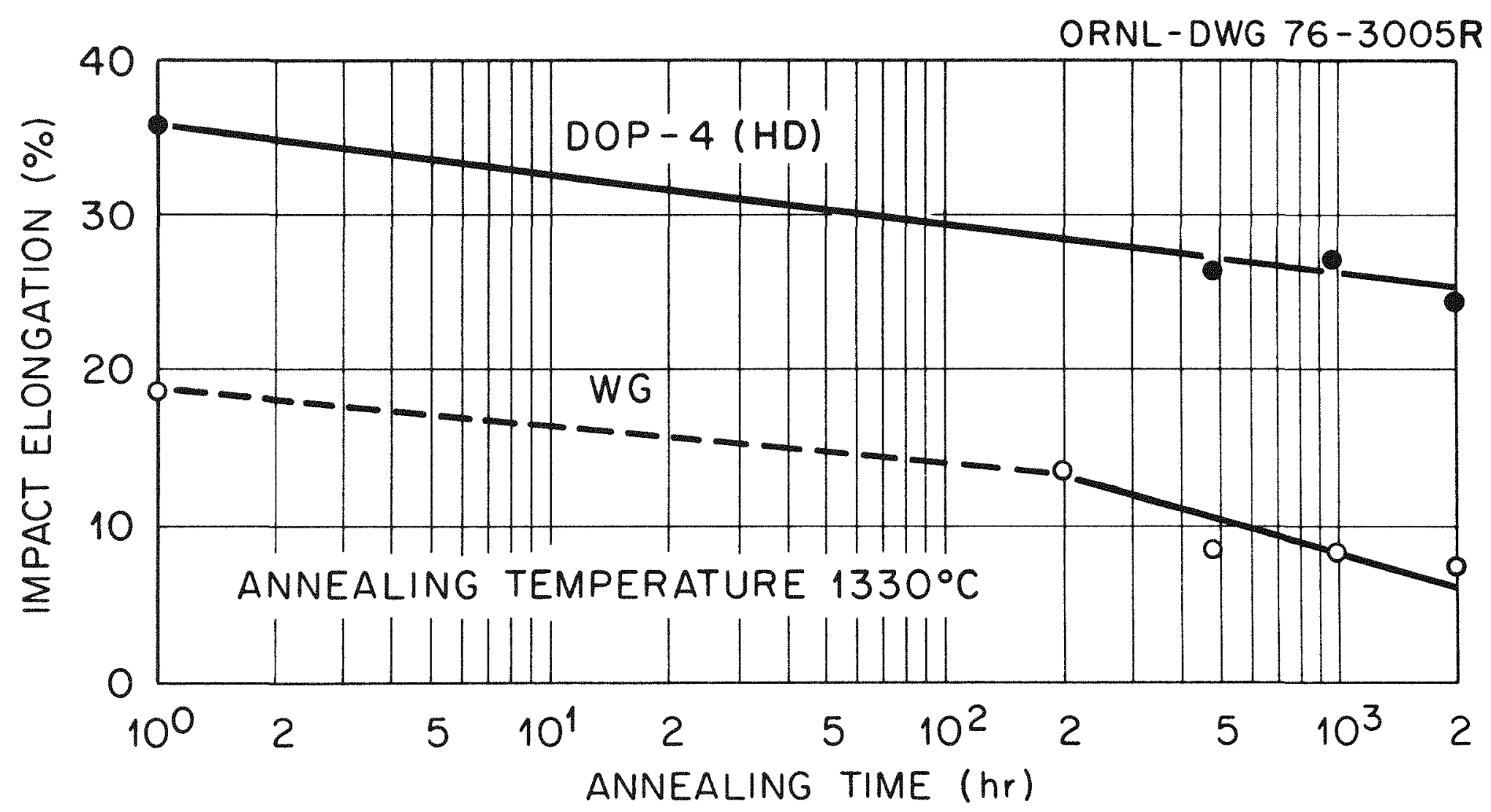

Fig. 2.3. Effect of Long-Term Annealing at $1330^{\circ} \mathrm{C}$ on Impact Elongation of WG and DOP-4. 


\subsection{Microanalysis Studies}

C. L. White, L. Heatherly, Jr., and R. E. Clausing

\subsubsection{Thorium Segregation to Grain Boundaries in $\operatorname{Ir}-0.3 \% \mathrm{~W}$}

Because thorium appears to significantly affect the grain boundary strength of Ir-0.3\% $\mathrm{W}$ alloys, it is of interest to determine the minimum thorium level that will result in acceptable grain boundary strength. In order to accomplish this, four experimental Ir $-0.3 \% \mathrm{~W}$ alloys have been prepared with dopant levels as indicated in Table 2.5. These alloys were electron-beam melted and drop cast using WG lot powder and the head and skull of WTh-2 (Ir-0.3\% W plus $100 \mathrm{ppm}$ Th) as a master alloy.

\section{Tab1e 2.5. Thorium Dopant Levels in Experimental} Heats of $\mathrm{Ir}-0.3 \% \mathrm{~W}$ Alloys

\begin{tabular}{cc}
$\begin{array}{c}\text { Heat } \\
\text { Designation }\end{array}$ & $\begin{array}{c}\text { Thorium } \\
\text { Dopant } \\
\text { Leve1 } \\
\text { (ppm) }\end{array}$ \\
\hline WTh-3 & 25 \\
WTh-4 & 10 \\
WTh-5 & 5 \\
WTh-6 & 50 \\
\hline
\end{tabular}

Samples of each of these alloys have been heat treated $1 \mathrm{hr}$ at $1500^{\circ} \mathrm{C}$, then analyzed using Auger electron spectroscopy (AES), to determine their grain boundary chemistry. ${ }^{*}$ The ratio, $R$, of the thorium (67 eV) peak height to the iridium ( $54 \mathrm{eV}$ ) peak height is plotted as a function of thorium dopant level in Fig. 2.4. It is clear that heat WTh-5, doped with only $5 \mathrm{ppm} \mathrm{Th}$, has approximately the same concentration of thorium on the grain boundaries as do alloys with $50 \mathrm{ppm}$ Th (WTh-1 and WTh-6).

If bulk chemical analysis verifies the thorium dopant levels in these alloys, impact testing of samples having small grain size will be considered.

\footnotetext{
*See reference no. 2 for a description of the experimental procedure.
} 
ORNL-DWG $76-13200$

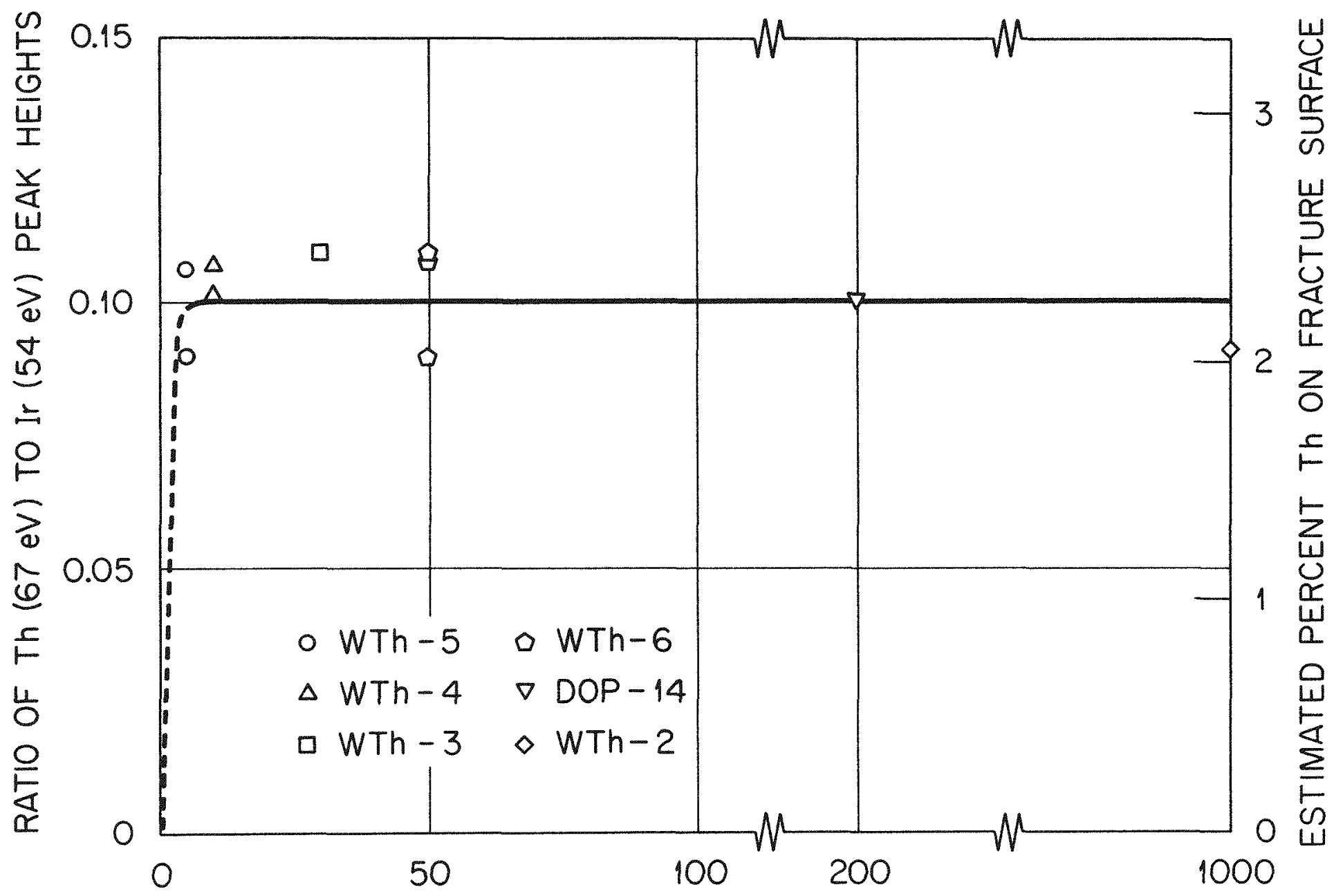

Fig. 2.4. Doping Leve1 for Thorium (wt ppm). 
If alloys with as little as $5 \mathrm{ppm}$ Th should have acceptable impact properties (given a small grain size), then alloy development efforts could concentrate on modifications specifically designed to control grain growth.

\subsubsection{Auger Electron Spectroscopy Analysis of DOP-17 and DOP-18}

Samples of DOP-17 ( Ir-2\% Ru-0.3\% W plus DOP-4 dopants) and DOP-18 ( Ir-2\% Ru-0.3\% W plus $200 \mathrm{ppm} \mathrm{Th}$ ) have been analyzed using AES. Both of these alloys had thorium segregated to the grain boundaries in approximately the same concentration as other thorium-doped alloys. . In addition to thorium and iridium, there was some indication of ruthenium on the fracture surface; however, interference between carbon and ruthenium would make a positive identification difficult.

\subsubsection{Phosphorus Segregation to Grain Boundaries in $\operatorname{Ir}-0.3 \% \mathrm{~W}$}

Because there is evidence that small concentrations of phosphorus in Ir-0.3\% W may significantly degrade its high-temperature impact properties, an experimental heat of $\mathrm{Ir}-0.3 \% \mathrm{~W}$ (IrP-3), doped with approximately $20 \mathrm{ppm} \mathrm{P}$, has been prepared by D. E. Harasyn. This alloy was arc melted and drop cast using a pressed and sintered $\mathrm{Ir}-2 \% \mathrm{P}$ compact as a master alloy. Because of the high vapor pressure of phosphorus, the amount of phosphorus retained in the cast alloy is uncertain, and bulk chemical analysis has not yet been obtained.

Preliminary AES analysis of two samples* of IrP-3 indicate very little phosphorus on the fresh fracture surfaces of the samples. Additional samples from various locations in the sheet will be analyzed to verify these results.

\subsection{Environmental and Impurity Effects}

\subsubsection{Pt-3008 Air Oxidation - H. Inouye}

Oxidation tests of Pt-3008 tensile specimens in still air, scheduled for $10,000 \mathrm{hr}$, logged $6000 \mathrm{hr}$ on June 17, 1976. Table 2.6 compares the tensile properties of oxidized specimens with the control and annealed

\footnotetext{
${ }^{*}$ Heat treated $1 \mathrm{hr}$ at $1500^{\circ} \mathrm{C}$.
} 
Tensile Properties of Pt-3008 (Heat Pt-5C) Oxidized in Still Air ${ }^{a}$

\begin{tabular}{|c|c|c|c|c|c|c|}
\hline \multicolumn{3}{|c|}{ Exposure Conditions } & \multicolumn{2}{|c|}{ Strength, $\mathrm{MPa}(\mathrm{ksi})$} & \multirow{2}{*}{$\begin{array}{c}\text { Elongation } \\
(\%)\end{array}$} & \multirow{2}{*}{$\begin{array}{c}\text { Reduction } \\
\text { of Area } \\
(\%)\end{array}$} \\
\hline $\begin{array}{l}\text { Time } \\
\text { (hr) }\end{array}$ & $\begin{array}{c}\text { Temperature } \\
\left({ }^{\circ} \mathrm{C}\right)\end{array}$ & Environment & U1timate & $\begin{array}{l}0.2 \% \\
\text { Yield }\end{array}$ & & \\
\hline \multicolumn{7}{|c|}{$600^{\circ} \mathrm{C}$} \\
\hline 1 & 1200 & Vac (Annealed) & $594.6(86.3)$ & $198.4(28.8)$ & 34.8 & $\sim 100$ \\
\hline 6024 & 600 & Vac (Control) & $630.4(91.5)$ & $228.1(33.1)$ & 32.5 & 79 \\
\hline 6024 & 600 & Air & $573.9(83.3)$ & $208.1(30.2)$ & 28.1 & 40 \\
\hline \multicolumn{7}{|c|}{$800^{\circ} \mathrm{C}$} \\
\hline 1 & 1200 & Vac (Annealed) & $540.2(78.4)$ & $182.6(26.5)$ & 28.5 & 78 \\
\hline 6024 & 800 & Vac (Control) & $470.6(68.3)$ & $223.2(32.4)$ & 26.1 & 38 \\
\hline 6024 & 800 & Air & $153.6(22.3)$ & $153.6(22.3)$ & 1.3 & $v_{0}$ \\
\hline \multicolumn{7}{|c|}{$1000^{\circ} \mathrm{C}$} \\
\hline 1 & 1200 & Vac (Annealed) & $311.4(45.2)$ & $170.2(24.7)$ & 13.2 & 12 \\
\hline 6000 & 1000 & Vac (Control) & $304.5(44.2)$ & $113.0(16.4)$ & 32.7 & 44 \\
\hline 5986 & 1000 & Air & $110.2(16.0)$ & $97.1(14.1)$ & 2.5 & $\sim_{0}$ \\
\hline
\end{tabular}

specimens. The tensile properties of oxidized Pt-3008, as well as the control specimens after $6000 \mathrm{hr}$, are comparable to those measured after $3000 \mathrm{hr}$ at all test temperatures. As noted previously and in the present test oxidation, temperatures of $600^{\circ} \mathrm{C}$ continue to have virtually no effect on the mechanical properties of the alloy; however, the alloy is embrittled by oxidation at 800 and $1000^{\circ} \mathrm{C}$.

The microstructures of the embrittled alloy after $3042 \mathrm{hr}$ at $1000^{\circ} \mathrm{C}$ in air are shown in Fig. 2.5. A coarse oxide phase is observed in the central regions of the specimen and a finely dispersed phase forms closer to the edges. Electron-microprobe examination shows that both the coarse and fine oxide phases are predominantly tungsten oxides.

\subsubsection{Grain Size Effects in $\mathrm{Pt}-3008-\mathrm{H}$. Inouye}

The tensile properties of Pt-3008 have been reported to degrade after exposure to $\mathrm{PuO}_{2}$ or to graphite at high temperatures; however, no evidence of a $\mathrm{PuO}_{2}$ or graphite interaction has been found. ${ }^{5,6}$ Therefore, the reason for the loss in strength and ductility of compatibility specimens could be due to grain growth or contamination of the alloy by impurities. 


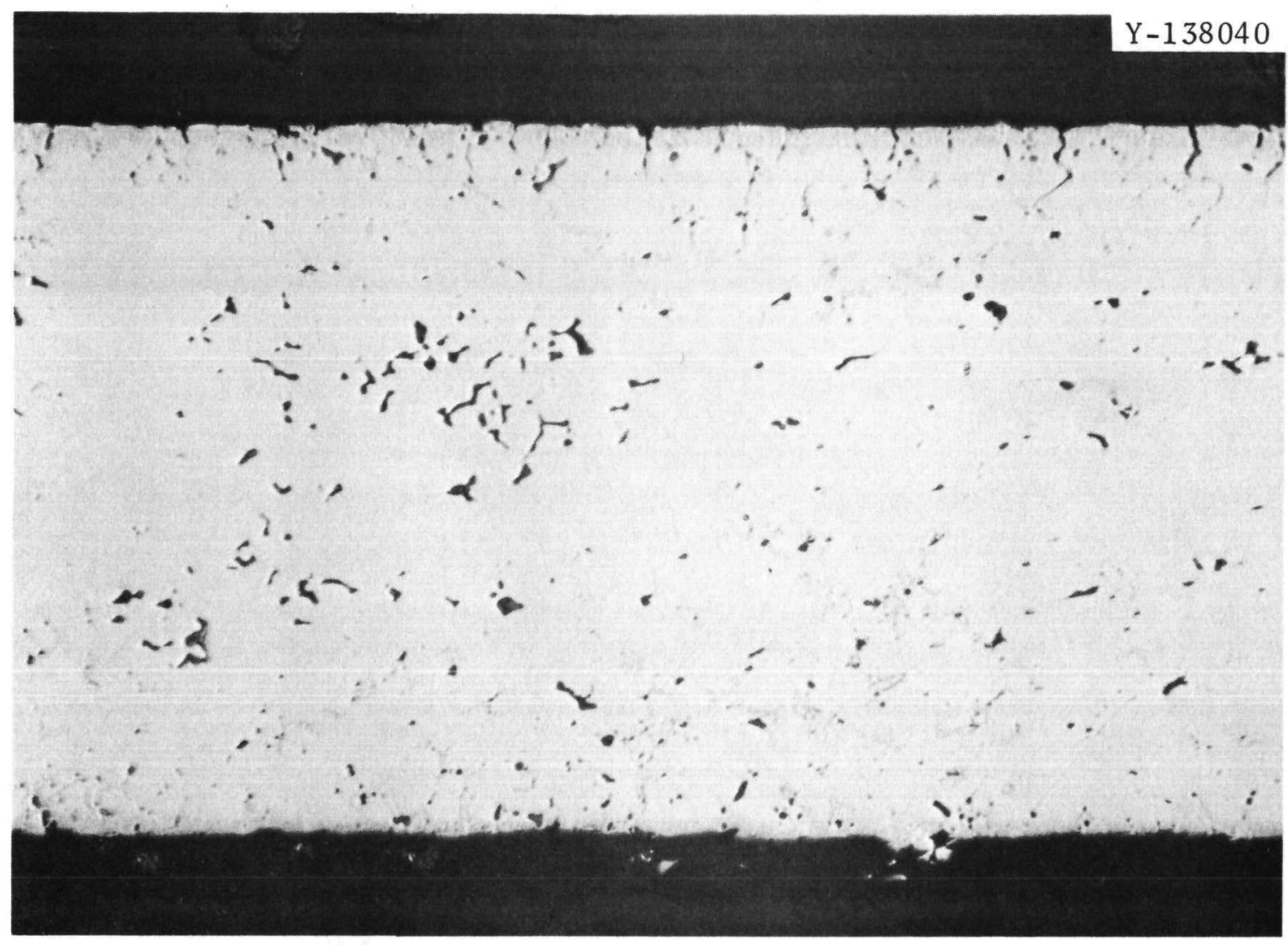

Fig. 2.5. As-Polished Pt-3008 0xidized $3042 \mathrm{hr}$ in Still Air. Both coarse and fine dark phases are tungsten oxides. 150×.

To determine the effect of grain size on the tensile properties, specimens were annealed at 1200 and $1500^{\circ} \mathrm{C}$ for times of 1 and $16 \mathrm{hr}$ in a noncontaminating environment. A summary of the results in Table 2.7 show (a) that both the ultimate and yield strengths decrease significantly with an increase in either the annealing temperature or the annealing time; (b) the ductility at $25^{\circ} \mathrm{C}$ is reduced to only $2.4 \%$ by a 16 -hr anneal at $1500^{\circ} \mathrm{C}$; however this heat treatment increases the ductility at 760,900 , and $1093^{\circ} \mathrm{C}$. Thus, these results clearly show that grain size has a large effect on the tensile properties of the alloy and is 1 ikely the major reason for the observed properties of long-term compatibility specimens.

\subsection{References}

1. A. C. Schaffhauser, Isotopic Power Materials Development Quart. Progr. Rep. Mar. 31, 1976, ORNL/TM-5482. 
Table 2.8. Effect of Heat Treatment on Tensile Properties of Pt-3008 (Heat E1-4B)

\begin{tabular}{|c|c|c|c|}
\hline \multirow{2}{*}{$\begin{array}{c}\text { Heat } \\
\text { Treatment }\end{array}$} & \multicolumn{2}{|c|}{ Strength, MPa(ksi) } & \multirow{2}{*}{$\begin{array}{c}\text { Elongation } \\
\left(\frac{0}{0}\right)\end{array}$} \\
\hline & Ultimate & $\begin{array}{c}0.2 \% \\
\text { Yield }\end{array}$ & \\
\hline \multicolumn{4}{|c|}{$25^{\circ} \mathrm{C}$} \\
\hline a & $695.2(100.9)$ & $348.6(50.6)$ & 16.4 \\
\hline $\mathrm{b}$ & $437.5(63.5)$ & $219.1(31.8)$ & 16.2 \\
\hline $\mathrm{c}$ & $216.4(31.4)$ & $195.7(28.4)$ & 2.4 \\
\hline \multicolumn{4}{|c|}{$760^{\circ} \mathrm{C}$} \\
\hline a & $547.8(79.5)$ & $196.4(28.5)$ & 28.2 \\
\hline $\mathrm{b}$ & $446.5(64.8)$ & $101.3(14.7)$ & 45.0 \\
\hline c & $356.2(51.7)$ & $81.3(11.8)$ & 42.8 \\
\hline \multicolumn{4}{|c|}{$\underline{900^{\circ} \mathrm{C}}$} \\
\hline a & $423.0(61.4)$ & $168.1(24.4)$ & 22.4 \\
\hline $\mathrm{b}$ & $340.4(49.4)$ & $91.6(13.3)$ & 38.6 \\
\hline c & $274.2(39.8)$ & $73.7(10.7)$ & 35.7 \\
\hline \multicolumn{4}{|c|}{$1093^{\circ} \mathrm{C}$} \\
\hline a & $241.8(35.1)$ & $141.3(20.5)$ & 14.6 \\
\hline $\mathrm{b}$ & $171.6(24.9)$ & $71.0(10.3)$ & 17.6 \\
\hline $\mathrm{c}$ & $113.7(16.5)$ & $62.0(9.0)$ & 16.0 \\
\hline \multicolumn{4}{|c|}{$1 \mathrm{hr}$ at $1200^{\circ} \mathrm{C}$} \\
\hline at $1500^{\circ} \mathrm{C}$ & $\begin{array}{l}\text { treatment: } \\
\text { lus } 1 \mathrm{hr} \text { at } 1\end{array}$ & $\begin{array}{l}\text { hr at } 1200^{\circ} \mathrm{C} \\
00^{\circ} \mathrm{C} \text {. }\end{array}$ & Ius $16 \mathrm{hr}$ \\
\hline
\end{tabular}

2. Ibid, p. 27 .

3. Ibid, pp. 43-50.

4. A. C. Schaffhauser, Isotopic Power Materials DeveZopment Quart. Progr Rep. Dec. 31, 1975, pp. 41-51.

5. D. L. Rphr and S. S. Hecker, Fracture Behavior of a Pt-30\% Rh-8\% W Alzoy Between Room Temperature adn $1300^{\circ} \mathrm{C}$, LA-UR-75-1189 (Ju1y 1975).

6. J. D. Watrous, Plutonia/Curia Compatibility Testing Monthly Report for July 1974, Donald W. Douglas Laboratories, Richland, Washington. 
Blank 


\section{ISOTOPE BRAYTON SYSTEM MATERIALS SUPPORT*}

\subsection{Introduction}

The objective of this program is to characterize the metallurgical and mechanical properties of materials and components selected for the Brayton Isotope Power System (BIPS) under the environmental and operating conditions expected for this system. Currently, emphasis is on the potential materials problems identified in the BTPS Ground Demonstration System (GDS), scheduled for operation in 1977. These potential materials problems include the effect of contaminants on the creep properties and tensile ductility of $\mathrm{C}-103(\mathrm{Nb}-10 \% \mathrm{Hf}-1 \% \mathrm{Ti}-0.7 \% \mathrm{Zr})$ in the heat exchanger, ducting, and turbine plenum; effects of aging and thermal cycling on the properties of $\mathrm{C}-103$ / Hastelloy $x$ bimetallic joints; and the mechanical properties of braze alloys used for fabrication of the Hastelloy $X$ recuperator. The magnitude of these potential materials problems and possible solutions are being investigated. Characterization of other key components including ducting and bellows will be performed. Additional tasks such as investigation of alternate materials and long-term creep tests will be initiated as required to insure the reliability of a flight system, scheduled for 1981 .

\subsection{C-103 Gaseous Interactions}

H. Inouye and C. T. Liu

\subsubsection{Creep Properties of C-103 in Contaminating Environments}

The creep strength of $\mathrm{C}-103$ has been measured in ultrahigh vacuum ${ }^{1}$ but not in the BIPS environment, which is expected to be both oxidizing and carburizing in the temperature range $700-1000^{\circ} \mathrm{C}$. A test just completed and those planned for the near future attempt to characterize the effects of specific gaseous impurities and effluents outgassed from system components on the creep behavior of the alloy.

A specimen was creep tested at $48.2 \mathrm{MPa}(7 \mathrm{ksi})$ and $1000^{\circ} \mathrm{C}$ in vacuum of $10^{-7}$ to establish base-line data followed by testing the same specimen

\footnotetext{
${ }^{*}$ Progress on work performed under Activity No. KJ 3001022,189 a No. 00006.
} 
in $1.3 \times 10^{-3} \mathrm{~Pa}\left(1 \times 10^{-5}\right.$ torr $) \mathrm{Co}$. A rectangular sheet specimen was also exposed to carbon monoxide in a separate apparatus at the same conditions because dilation has been found to be one of the important effects of the contamination of tantalum. ${ }^{2}$ Creep data based on tests of about $300 \mathrm{hr}$ (Table 3.1) shows that $\mathrm{C}-103$ creeps slower in carbon monoxide than in vacuum. Because dilation of the unstressed specimen was about $40 \%$ of the total creep strain measured in carbon monoxide at $48.2 \mathrm{MPa}$ ( $7 \mathrm{ksi}$ ), the creep rate of C-103 that can be attributed to stress is calculated to be about onethird of the rate in vacuum. A post mortem of the creep specimen (Table 3.2) confirms the expected contamination of the alloy with carbon and oxygen, its embrittlement, and the protective effect of getter foils.

Table 3.1. Effect of the Environment on the Creep Rate of $\mathrm{C}-103$ at $1000^{\circ} \mathrm{C}^{\mathrm{a}}$

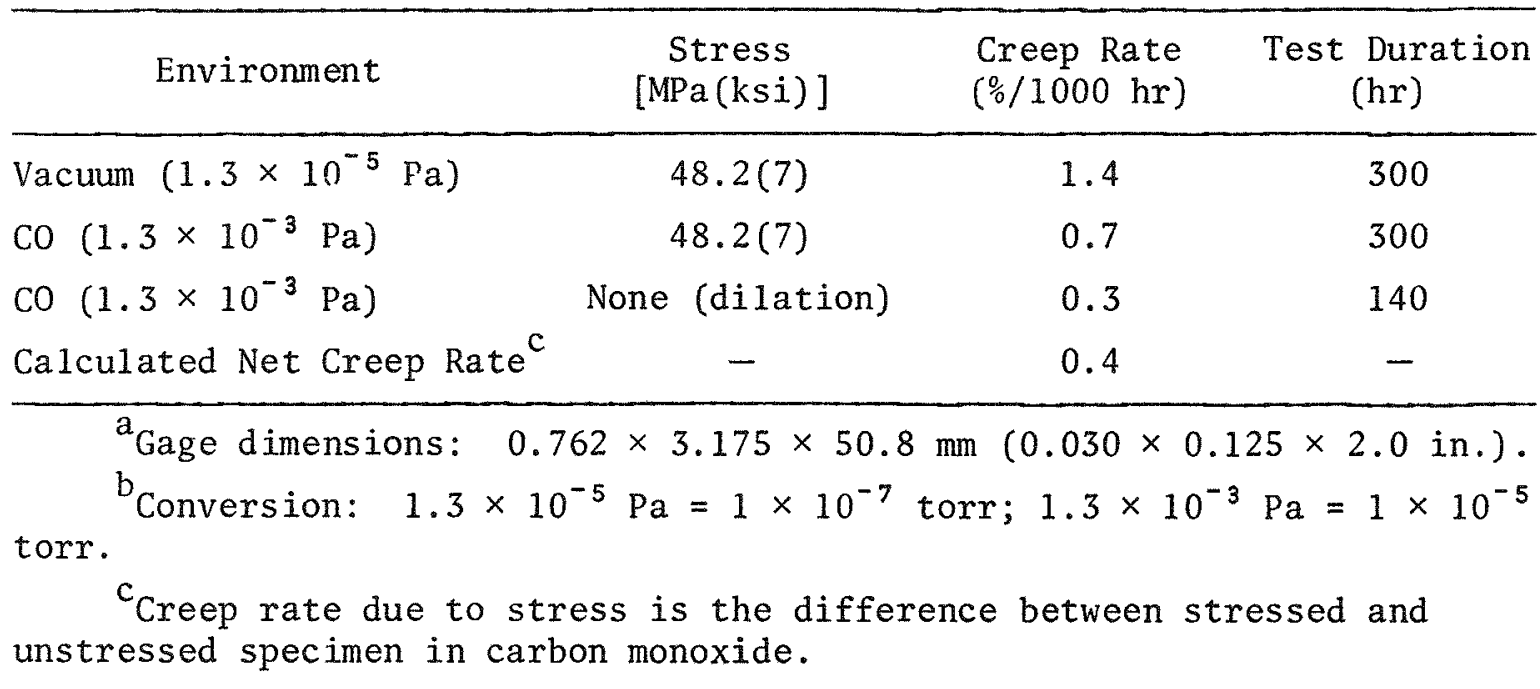

\subsubsection{Effect of Gaseous Environment on Embrittlement of C-103}

To study the embrittlement effects of the carbon monoxide gas environment, tensile sheet specimens of $\mathrm{C}-103$ were vacuum annealed $1 \mathrm{hr}$ at $1650^{\circ} \mathrm{C}$ and then exposed to carbon monoxide gas at a pressure of $1.3 \times 10^{-3} \mathrm{~Pa}$ $\left(1 \times 10^{-5}\right.$ torr $)$ at $1000^{\circ} \mathrm{C}$. The specimens showed almost no indication of surface films up to $200-\mathrm{hr}$ exposure. The average weight gain for the tensile specimens is $18 \mathrm{ppm} / \mathrm{hr}$ [in terms of $0.762-\mathrm{mm}-(0.030-\mathrm{in} .-)$ thick specimens]. The tensile properties of the annealed and exposed specimens 
Table 3.2. Post Mortem of $\mathrm{C}-103$ Creep Tested in $1.3 \times 10^{-3} \mathrm{~Pa}\left(1 \times 10^{-5}\right.$ torr $) \mathrm{CO}$ at $1000^{\circ} \mathrm{C}^{\mathrm{a}}$

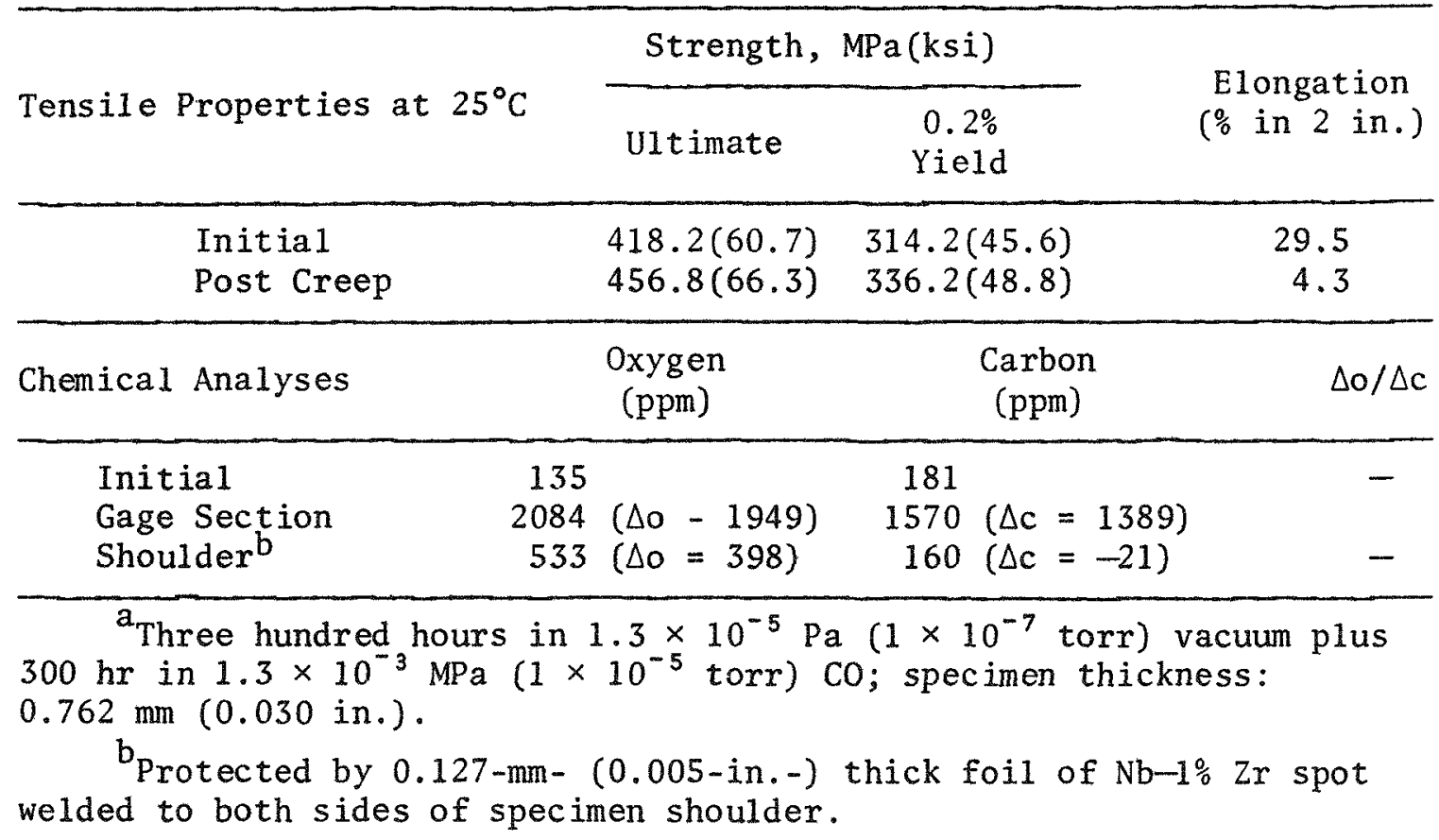

were determined at room temperature, $800^{\circ} \mathrm{C}$, and $1000^{\circ} \mathrm{C}$; the results are presented in Table 3.3 and plotted as a function of weight gain in Fig. 3.1.

Table 3.3. Tensile Properties of $\mathrm{C}-103$ Sheet Specimens ${ }^{\mathrm{a}}$ Exposed to Carbon Monoxide Gas at $1000^{\circ} \mathrm{C}$ and $1.3 \times 10^{-3} \mathrm{~Pa}$

$\left(1 \times 10^{-5}\right.$ torr $)$ Pressure

\begin{tabular}{|c|c|c|c|}
\hline \multirow{2}{*}{$\begin{array}{l}\text { Weight } \\
\text { Gain } \\
\text { (ppm) }\end{array}$} & \multirow{2}{*}{$\begin{array}{c}\text { Elongation } \\
\left(\begin{array}{c}0 \\
0\end{array}\right)\end{array}$} & \multicolumn{2}{|c|}{ Strength, MPa(ksi) } \\
\hline & & Yield & Tensile \\
\hline \multicolumn{4}{|c|}{ Room Temperature } \\
\hline $\begin{array}{r}{ }^{0} \\
1816^{b} \\
3928^{c}\end{array}$ & $\begin{array}{r}29.5 \\
14.5 \\
2.3\end{array}$ & $\begin{array}{l}314.2(45.6) \\
319.0(46.3) \\
335.5(48.7)\end{array}$ & $\begin{array}{l}418.2(60.7) \\
420.3(61.0) \\
397.5(57.7)\end{array}$ \\
\hline \multicolumn{4}{|c|}{$850^{\circ} \mathrm{C}$} \\
\hline $\begin{array}{r}{ }^{0} \\
2052^{b} \\
4205^{c}\end{array}$ & $\begin{array}{r}22.1 \\
7.4 \\
2.5\end{array}$ & $\begin{array}{l}139.2(20.2) \\
212.2(30.8) \\
283.2(41.1)\end{array}$ & $\begin{array}{l}287.3(41.7) \\
303.2(44.0) \\
306.6(44.5)\end{array}$ \\
\hline \multicolumn{4}{|c|}{$1000^{\circ} \mathrm{C}$} \\
\hline $\begin{array}{r}{ }^{0} b \\
2107^{b} \\
4124^{c}\end{array}$ & $\begin{array}{r}20.5 \\
10.0 \\
2.3\end{array}$ & $\begin{array}{l}137.8(20.0) \\
210.1(30.5) \\
267.3(38.8)\end{array}$ & $\begin{array}{l}281.1(40.8) \\
288.7(41.9) \\
305.9(44.4)\end{array}$ \\
\hline
\end{tabular}


ORNL-DWG 76-11275

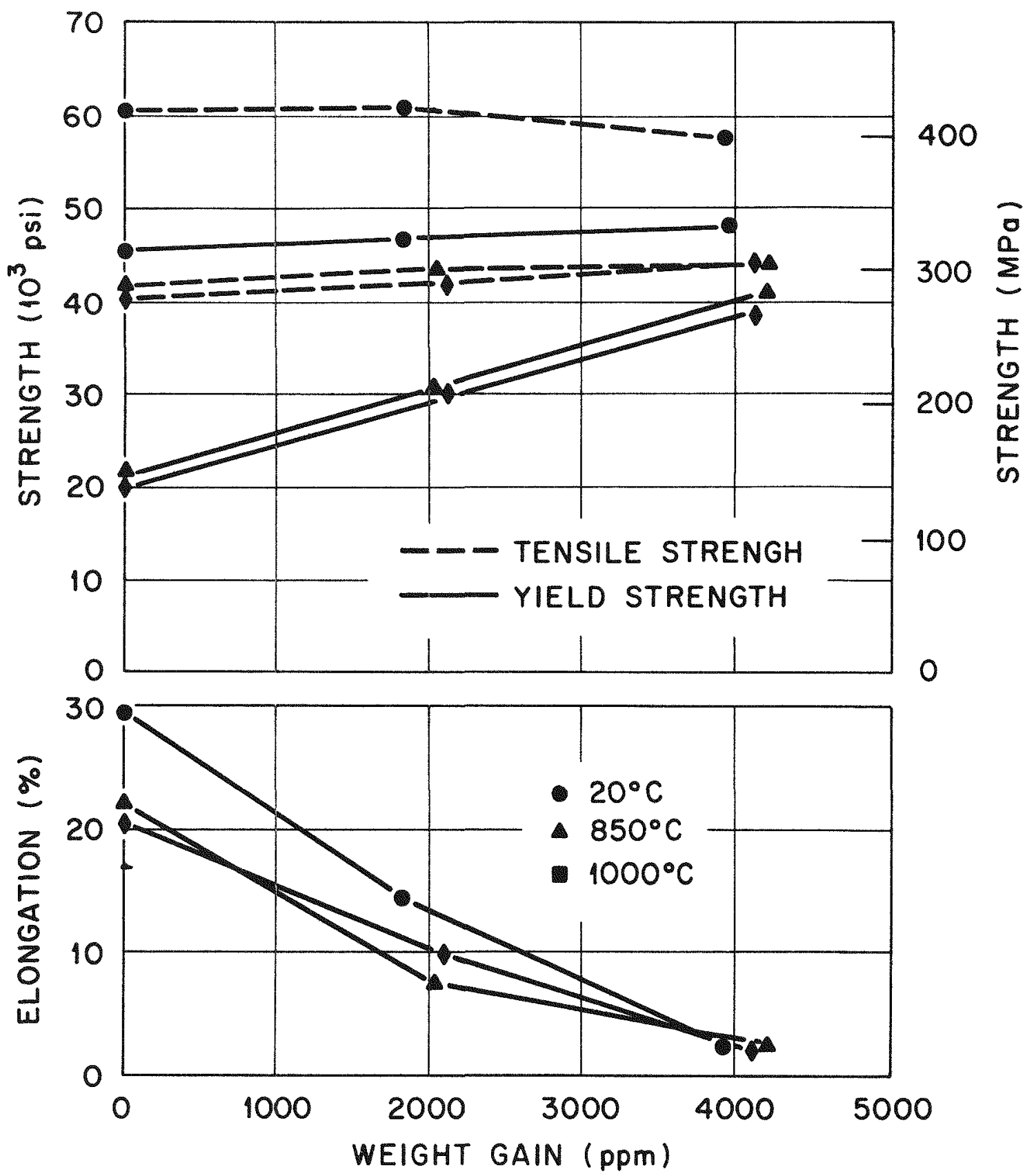

Fig. 3.1. Plot of Tensile Data as a Function of Weight Gain for $\mathrm{C}-103$ Specimens Exposed to Carbon Monoxide Gas at $1000^{\circ} \mathrm{C}$ at a Pressure of $1.3 \times$ $10^{-3} \mathrm{~Pa}\left(1 \times 10^{-5}\right.$ torr $)$. 
The yield strength at 850 and $1000^{\circ} \mathrm{C}$ increases 1 inearly with weight gain, but the yield strength at room temperature and the tensile strength at the three test temperatures are relatively insensitive to the weight gain. The tensile ductility of the $\mathrm{C}-103$ specimens decreases seriously with increasing weight gain or exposure time at $1000^{\circ} \mathrm{C}$. The elongation of $\mathrm{C}-103$ specimens was reduced from $20-30 \%$ to $2.3-2.5 \%$ at these three test temperatures after approximately $200 \mathrm{hr}$ of exposure (weight gain $\simeq 4000 \mathrm{ppm}$ ) at $1000^{\circ} \mathrm{C}$.

The specimen which showed a weight gain of 3928 ppm was sent to vacuum fusion and carbon analyses. The result indicates that this specimen absorbed $1627 \mathrm{ppm} \mathrm{C}$ and $2315 \mathrm{ppm} \mathrm{0,} \mathrm{a} \mathrm{tota1} \mathrm{of} 3942 \mathrm{ppm}$. The carbon-to-oxygen ratio is 1.42 , which agrees reasonably well with a value of 1.5 , reported $^{3}$ for exposure of tantalum to carbon monoxide gas around $1000^{\circ} \mathrm{C}$.

\subsection{Alternate Alloys \\ H. Inouye and C. T. Liu}

\subsubsection{Creep Properties of Molybdenum-Rhenium Alloys}

We characterize the creep properties of molybdenum-rhenium alloys in order to consider them as a back-up material for the Isotope Brayton System. Sheet specimens of Mo-45\% Re and Mo-33\% Re alloys, prepared by electronbeam melting, were tested in creep at $1000^{\circ} \mathrm{C}$ at a stress of $96.5 \mathrm{MPa}$ (14 $\mathrm{ksi}$ ) in a vacuum of $1.3 \times 10^{-4} \mathrm{~Pa}\left(1 \times 10^{-6}\right.$ torr $)$. The 1000 -hr creep tests indicate that the creep strengths (in terms of time for $1 \%$ creep strain) of $\mathrm{C}-103$ and Mo-45\% Re are comparable to each other at $1000^{\circ} \mathrm{C}$. The Mo- $33 \%$ Re alloy is much stronger in creep and its creep rate is lower than that of Mo-45\% $\operatorname{Re}$ and $\mathrm{C}-103$ by a factor of 55 .

\subsubsection{Creep Properties of Pt-3008}

The creep tests of $\mathrm{Pt}-3008$ at $1000^{\circ} \mathrm{C}$ in vacua of approximately $1.3 \times$ $10^{-4} \mathrm{~Pa}\left(1 \times 10^{-6}\right.$ torr $)$ are in progress. The data show that the time required to produce $1 \%$ strain at $34.5 \mathrm{MPa}(5 \mathrm{ksi})$ is $136.9 \mathrm{hr}$ and $48.6 \mathrm{hr}$ at $48.2 \mathrm{MPa}(7 \mathrm{ksi})$. The time required to produce $1 \%$ strain in $\mathrm{C}-103$ at $48.2 \mathrm{MPa}(7 \mathrm{ksi})$ and $1000^{\circ} \mathrm{C}$ is reported to be about $1000 \mathrm{hr}$. 
3.4 Welding and Brazing Evaluation

G. M. Goodwin

Lap-shear specimens have been prepared with Hastelloy $x$ brazed to itself with Palniro 7 ( $\mathrm{Au}-8 \% \mathrm{Pd}-22 \% \mathrm{Ni}$ ). A joint spacing of $0.0762 \mathrm{~mm}$ ( 0.003 in.) was used, controlled both by nickel wire spacers and the braze alloy foil itself. After placement of the spacers, the specimens were autogeneously tack welded prior to brazing.

Dissimilar metal lap-shear specimens have also been prepared between Haste1loy $X$ and $\mathrm{C}-103$ alloy sheet using Coast Metals 50 (Ni-3.5\% Si-2.5\% $\mathrm{B}-1 \% \mathrm{Fe}$ ) braze alloy in powder form. Spacing was accomplished with nickel wires, and tack welds were made with Inconel 82 filler metal due to the extreme brittleness of the direct fusion weld.

Both sets of specimens are being machined for short-term tensile tests and aging studies.

\subsection{References}

1. W. D. Klopp and R. H. Titran, Interim Analysis of Long-Time Creep Behavior of Columbium C-Z03 AZZoy, NASA TM X-71895 (March 1976).

2. J. B. Conway, R. M. Fince1, Jr., and A. C. Losekamp, Trans. AIME 233 (April 1965), p. 841-2.

3. M. D. Ketchum and C. A. Barrett, Contamination of Refractory Metals by Oxygen, Water Vapor, and Carbon Monoxide, NASA-CR-1537 (May 1970). 


\section{SPACE NUCLEAR FLIGHT SYSTEMS HARDWARE*}

\subsection{Introduction}

The 1 imited-scale production of high-quality iridium alloy sheet and foil, based on ORNL-developed procedures, is performed in this task. Forming disks are machined from sheet and are supplied to Mound Laboratory for hot hydroforming into hemispheres which encapsulate the ${ }^{238} \mathrm{PuO}_{2}$ isotope fuel spheres and serve as the Post-Impact Containment Shells (PICS) of the Multi-Hundred Watt (MHW) Heat Source. Iridium alloy foil is also supplied for forming weld shields and decontamination covers during processing the PICS. Extensive quality assurance and characterization of material, along with a limited amount of process improvement development, is performed in this task.

4.2 Production of $\operatorname{Ir}-0.3 \%$ W Forming Disks and Foil

$$
\text { D. E. Harasyn }
$$

Production data on Ir $-0.3 \% \mathrm{~W}$ forming disks produced in April, May, and June of 1976 are shown in Table 4.1. We completed our required shipment of forming disks for the MJS mission with the shipment of HD 451-456 and began production for the HPG/Mod-3. Our present schedule calls for shipment of 20 disks to Mound Laboratory every three weeks.

Approximately $1000 \mathrm{~cm}^{2}$ (157 in. ${ }^{2}$ ) of $\mathrm{Ir}-0.3 \% \mathrm{~W}$ foil was shipped to Mound Laboratory this quarter. It is expected that this shipment will meet Mound Laboratory's foil requirements for the MJS mission. We have requested the approval of Mound Laboratory to change our procedures so that foil is no longer recrystallized before shipment. Recrystallized I $-0.3 \% \mathrm{~W}$ is very soft and easily damaged, which makes packaging of the foil very difficult. In the cold-worked state, however, the foil is very hard and resistant to damage during handling and packaging.

Surface microdelaminations that have shown up on most of the PICS production metallography samples from HD 427-462 appear to be only an artifact

\footnotetext{
${ }^{*}$ Progress on work performed under Activity No. KJ $3001032,189 \mathrm{a}$ No. 00003 .
} 
Table 4.1. PICS Production Data

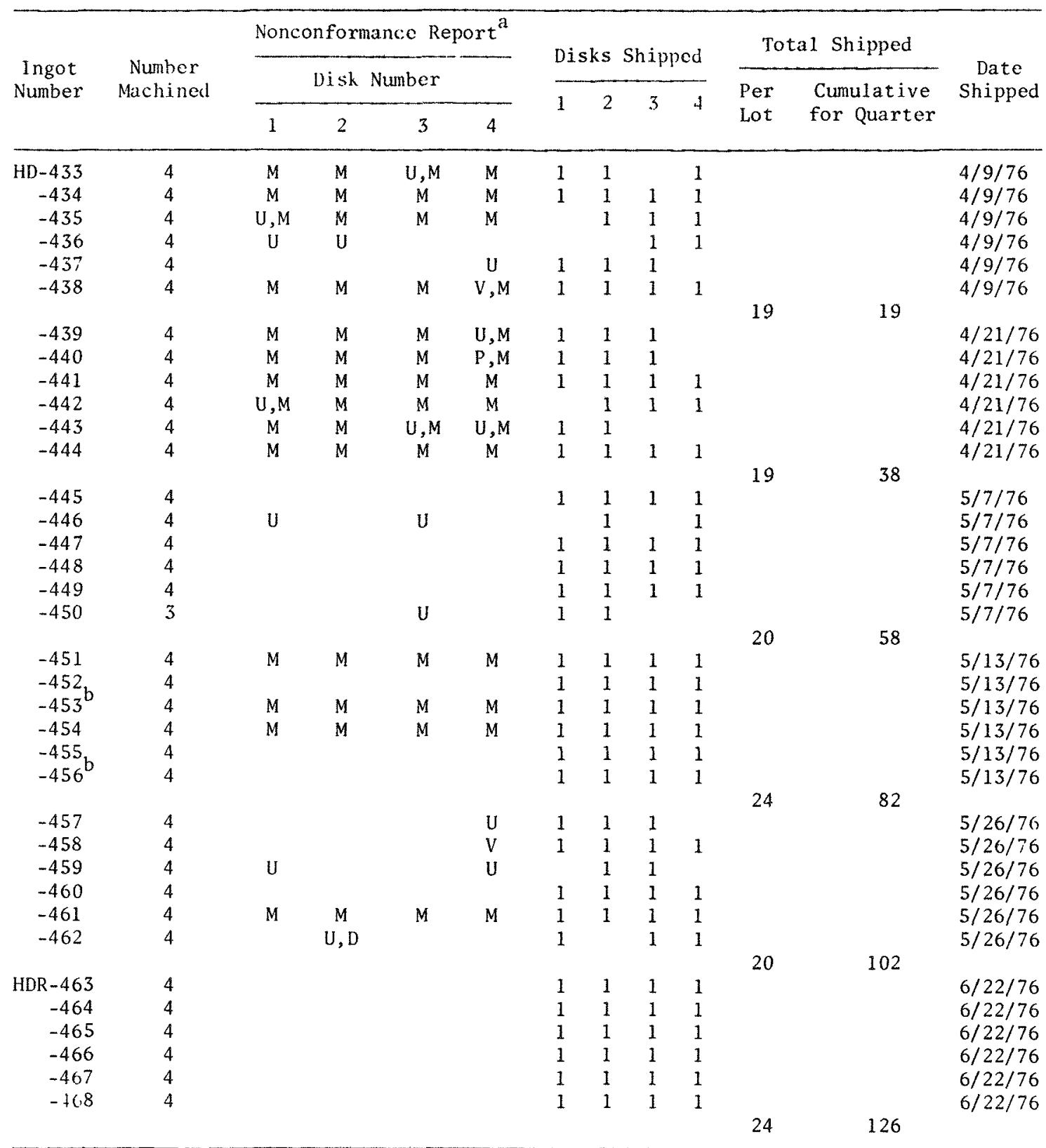

${ }_{D}=$ dimensional $; U=$ ultrasonic; $P=$ dye penetrant $V=v i s u a l ;$ and $M=$ metallography.

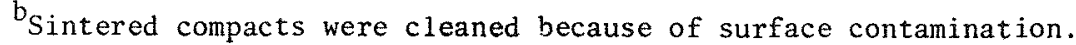


of the metallographic preparation. It has been demonstrated that a chemical or metallurgical difference in the lot HD 427-432 (first lot to show delaminations) from previous lots could not account for the delaminations. ${ }^{1}$

A second experiment involved material that had been examined metallographically prior to HD 427-432 and had shown no delaminations. When this material was metallographically prepared some time after HD 427-432, it contained the surface delaminations. This led to an investigation of our metallographic procedure to determine the cause of the delaminations. A review of our data indicated that virtually any sample submitted after HD 427-432 that was surface ground and in the wrought condition was likely to be delaminated on the surface no matter what was done to it prior to the metallographic preparation.

A lack of edge support was thought to be the most 1ikely cause of the surface delaminations. To establish this, we remounted and repolished a set of production samples from HD 439-444. All had failed the metallography inspection because of surface delaminations. The worst three of the six (HD-439, -440, and -444) were dissolved from their epoxy mounts and remounted in Plastimet (Buehlex Ltd.). This new mounting material has a hardness of approximately $70 \mathrm{DPH}$ as compared to the epoxy material which has a hardness of about $7 \mathrm{DPH}$. The new motnting material was advertised as having excellent edge-retaining qualities. The three samples that were remounted and repolished in Plastimet mounts contained no surface delaminations. Al1 three of the samples that were left in their epoxy mounts and repolished at the same time with the samples mounted in plastimet contained surface delaminations. These delaminations were severe enough to result in a failure of the metallographic certification. The edges of the samples mounted in Plastimet appeared very clean and straight, whereas the edges of samples mounted in epoxy appeared very rough, ragged, and sometimes cracked. Lack of edge support is thought to have been the most likely cause of the surface delaminations in all of our samples mounted in epoxy since HD 427-432. We suspect that the hardener for the epoxy was at fault, but the hardener is no longer traceable and further experiments are costly.

PICS production samples from HDR 463-468 were mounted in Plastimet, and none of these samples had evidence of surface delaminations. No experiments are planned to further investigate this problem because we believe our evidence pointing toward lack of edge support is solid. We intend to use Plastimet as the mounting material for all our production samples in the future. 


\subsection{Impact Properties of Production Material}

C. T. Liu

We are continuing to qualify the impact properties of DOP-4-type Ir-0.3\% $\mathrm{W}$ production material used for space nuclear flight systems hardwares. Sheet specimens were blanked from heats HD-403, $-436,-440$, and -459 , heat treated $19 \mathrm{hr}$ at $1500^{\circ} \mathrm{C}$, then impacted at $85 \mathrm{~m} / \mathrm{sec}(280 \mathrm{fps})$ at $1350^{\circ} \mathrm{C}$. The results are presented in Table 4.2 together with those obtained previously from different lots of production material. The production lots HD-403 to -459 , produced by electron-beam melting of $40 \%$ powder compacts and $60 \%$ recycled heads and skulls from the proceeding lot of HD ingots, had the impact ductility of 15.8-20.8\% which is generally lower than for lot DOP-4(0.3\% W) -1 and HD-400 (produced from all powder compacts). As reported previously, ${ }^{2}$ the lower ductility is probably due to loss of the aluminum dopants on successive electron-beam melts. Since the HD production material has more than $14 \%$ impact elongation, it should survive the MHW/FSA-type impact test.

\subsection{References}

1. A. C. Schaffhauser, Isotopic Power Materials Development Quart. Progr. Rep. Mar. 31, 1976, ORNL/TM-5482, p. 67.

2. A. C. Schaffhauser, Isotopic Power Materials Development Quart. Progr. Rep. Mar. 31, 1976, ORNL/TM-5482. 
Table 4.2. Tensile Impact Properties of Ir-0.3\% W Alloy Sheet Annealed $19 \mathrm{hr}$ at $1500^{\circ} \mathrm{C}$ and Tested at

$85 \mathrm{~m} / \mathrm{sec}(280 \mathrm{fps})$ at $1350^{\circ} \mathrm{C}$

\begin{tabular}{|c|c|c|c|c|}
\hline $\begin{array}{l}\text { Heat } \\
\text { Number }\end{array}$ & $\begin{array}{l}\text { Grain } \\
\text { Size }^{a}\end{array}$ & $\begin{array}{l}\text { Elongation } \\
\left(\begin{array}{c}\% \\
\%\end{array}\right)\end{array}$ & $\begin{array}{c}\text { Reduction } \\
\text { of Area } \\
(\%)\end{array}$ & Fracture Mode ${ }^{b}$ \\
\hline$W G-65^{c}$ & 3.4 & 9.6 & 21 & Main1y GBS \\
\hline$W G-204^{C}$ & 3.8 & 10.7 & 23 & Main1y GBS \\
\hline DOP-4 $(0.3 \% W)-1{ }^{d}$ & 9.9 & 26.8 & 60 & $\mathrm{TF}$ and $\mathrm{DR}$ \\
\hline WGD $-271^{e}$ & 8.4 & 18.2 & 45 & $\mathrm{TF}(\mathrm{Ma})$ and $\mathrm{GBS}(\mathrm{Mi})$ \\
\hline $\mathrm{HD}-400^{\mathrm{f}}$ & 10.3 & 21.1 & 52 & Mainly $\mathrm{TF}$ \\
\hline $\mathrm{HD}-403^{\mathrm{g}}$ & 8.6 & 20.8 & 50 & Mainly $\mathrm{TF}$ \\
\hline $\begin{array}{l}\mathrm{HD}-416^{g, h} \\
\mathrm{HD}-416^{g, h}\end{array}$ & $\begin{array}{c}8.0 \\
-\end{array}$ & $\begin{array}{l}18.1 \\
14.8\end{array}$ & $\begin{array}{l}45 \\
36\end{array}$ & $\begin{array}{l}\text { TF (Ma) and GBS (Mi) } \\
\text { TF and GBS }\end{array}$ \\
\hline $\begin{array}{l}\mathrm{HD}-428^{g, h} \\
\mathrm{HD}-428^{g, h}\end{array}$ & $\begin{array}{c}8.9 \\
-\end{array}$ & $\begin{array}{l}15.2 \\
16.5\end{array}$ & $\begin{array}{l}39 \\
42\end{array}$ & $\begin{array}{l}\mathrm{TF} \text { and GBS } \\
\mathrm{TF} \text { (Ma) and GBS (Mi) }\end{array}$ \\
\hline $\mathrm{HD}-436^{\mathrm{g}}$ & 8.1 & 18.5 & 46 & TF (Ma) and GBS (Mi) \\
\hline $\mathrm{HD}-440^{\mathrm{g}}$ & - & 20.5 & 59 & Main1y TF \\
\hline $\mathrm{HD}-459^{\mathrm{g}}$ & - & 18.9 & 57 & Mainly TF \\
\hline
\end{tabular}

${ }^{a}$ Number of grains across a $0.64-\mathrm{mm}(0.025$-in.) sheet thickness.

${ }_{\mathrm{GBS}}=$ grain-boundary separation; $\mathrm{TF}=$ transgranular fracture; $\mathrm{DR}=$ ductile rupture; $\mathrm{Ma}=$ major fraction; and $\mathrm{Mi}=$ minor fraction.

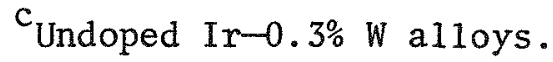

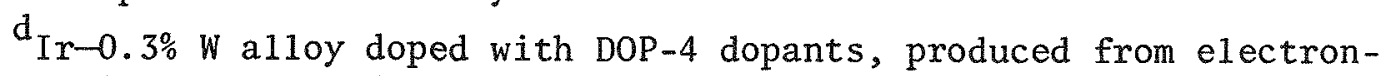
beam melting of WG powder compacts.

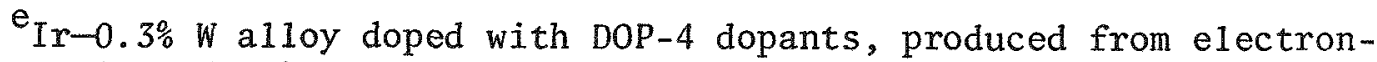
beam melting of $40 \%$ WG powder compacts and $60 \%$ WG recycled sku1ls and heads.

$f_{I x-0.3 \% W}$ alloy doped with DOP-4 dopants, produced from electronbeam melting of HD powder compacts.

$\mathrm{g}_{\mathrm{Ir}-0.3 \%} \mathrm{~W}$ alloy doped with DOP -4 dopants, produced from electronbeam melting of $40 \% \mathrm{HD}$ powder compacts and $60 \% \mathrm{HD}$ recycled sku1ls and heads.

huplicate tests. 
Blank 
ORNL/TM-5569

\section{INTERNAL DISTRIBUTION}

1. D. N. Braski

2. C. R. Brinkman

3. J. A. Carter

4. R. E. Clausing

5. J. E. Cunningham

6. J. H. DeVan

7. J. R. DiStefano

8. R. G. Donnelly

9. J. I. Federer

10. G. M. Goodwin

11. J. P. Hammond

12. D. E. Harasyn

13. R. L. Heestand

14. M. R. Hil1

15. H. Inouye

16. E. Lamb

17. C. T. Liu

18. M. M. Martin
19. W. R. Martin

20. R. E. McDonald

21. C. L. Ottinger

22. P. Patriarca

23. H. Postma

24-28. A. C. Schaffhauser

29. G. M. Slaughter

30. J. 0. Stiegler

31. V. J. Tennery

32. D. B. Trauger

33. J. R. Weir, Jr.

34. C. L. White

35. R. 0. Williams

36-37. Centra1 Research Library

38. Document Reference Section

39-43. Laboratory Records

44. Laboratory Records, ORNL RC

45. ORNL Patent office

\section{EXTERNAL DISTRIBUTION}

46-47. AiResearch Manufacturing Company of Arizona, 402 South 36 th Street, P.O. Box 5217, Phoenix, AZ 85010

J. R. Hadley

J. E. McCormick

48-49. Batte1le Memorial Institute, 505 King Avenue, Columbus, OH 43201

C. Alexander

W. Pardue

50. Battelle's Pacific Northwest Laboratories, Battelle Blvd., Richland, WA 99352

H. Fullam

51. Cabot Corporation, Stellite Division, 1020 Park Avenue, Kokomo, IN 46901

J. Tackett

52. Engelhard Industries, 700 Blair Road, Carteret, NJ 07008

H. J. Albert

53. Fairchild Space and Electronics Company, Germantown, MD 20767

A. Schock 
54. General Electric Company, Materials Technology, Energy Systems Programs, 1 River Road, Schenectady, NY 12345

R. G. Frank

55. General Electric Company, Nuclear Programs, P.0. Box 8661, Philadelphia, PA 19101

E. W. Williams

56. Gulf Energy and Environmental Systems, P.0. Box 608, San Diego, CA 92112

N. Elsner

57. Kirtland Air Force Base, NM 87117

Directorate of Nuclear Safety

58-60. Los Alamos Scientific Laboratory, P.0. Box 1663, Los Alamos, NM 87545

R. D. Baker

S. E. Bronisz

S. Hecker

61. Minnesota Mining and Manufacturing Company, 2501 Hudson Road,

St. Paul, NM 55119

E. F. Hamp 1

62-63. Monsanto Research Corporation, P.0. Box 32, Miamisburg, OH 45342

W. T. Cave/D. P. Kelly

E. W. Johnson/D. L. Coffey

64-65. Savannah River Laboratory, E. L. DuPont de Nemours and Company, Aiken, SC 29801

R. Gregg

J. R. Hilley

66. Sunstrand Energy Systems, 4747 Harrison Avenue, Rockford, IL 61101

E. Kreuger

67-68. Teledyne Energy Systems, 110 W. Timonium Road, Timonium, MD 21093

W. J. Barnett

W. Osmeyer

69. USERDA Dayton Area Office, P.0. Box 66, Miamisburg, OH 45342

E. A. Walker 
70-82. USERDA Division of Nuclear Research and Applications, Washington, DC 20545
R. T. Carpenter
A. L. Mowery
T. J. Dobry
G. A. Newby
N. Goldenberg
B. J. Rock
T. J. Holleman
C. O. Tarr
W. D. Kenney
N. R. Thielke
A. P. Litman
E. J. Wah1quist
J. J. Lombardo

83. USERDA Division of Reactor Research and Development, Washington, DC 20545

J. M. Simmons

84. USERDA Oak Ridge Operations Office, P.O. Box E, Oak Ridge, TN 37830 Research and Technical Support Division

85. USERDA Office of Program Coordination and Management - Reactors and Space, 1333 Broadway, Oakland, CA 94612

W. L. Von Flue

86. USERDA Savannah River Operations Office, P.O. Box "A", Aiken, SC 29801 L. M. East

87-113. USERDA Technical Informantion Center, Office of Information Services, P.0. Box 62, Oak Ridge, TN 37830

114. USNASA Headquarters, Washington, DC 20546

T. B. Kerr

115. USNASA Jet Propulsion Laboratory, Ca1ifornia Institute of Technology, 4800 Oak Grove Drive, Pasadena, CA 91103

V. Trusce110

116-117. USNASA Lewis Research Center, 2100 Brookpark Road, Cleveland, OH 44135
M. Ault
R. Migra
R. H. Titran 